Studia Anglica Posnaniensia 52(3), 2017

doi: 10.1515/stap-2017-0011

\title{
INTENSITY OF THE READER'S VOICE IN THE READING ALOUD OF FICTION: EFFECTS OF THE CHARACTER'S GENDER
}

\author{
ŁUKASZ STOLARSKI*
}

Institute of Foreign Languages, Jan Kochanowski University in Kielce

\begin{abstract}
The speaker's gender is a crucial factor affecting the acoustic features of the voice. One such feature is voice intensity, also known as sound pressure level (SPL). Previous studies have indicated that the female voice may involve lower values of SPL than the male voice. Moreover, there are suggestions that the variability of voice intensity tends to be lower for women than for men as well.

The major aim of this paper is to examine the effects of literary character's gender on the reader's SPL, measured in decibels $(\mathrm{dB})$, and the variability of voice intensity, measured as the standard deviation (SD) of SPL, while reading prose aloud. The secondary aims are to investigate the general shifts of SPL and SD of SPL in dialogues independently of other variables and to consider the possible effects of the reader's gender and the reader's dialect. In order to accomplish these tasks, a representative sample of dialogue excerpts with male and female characters was used. Each fragment was located in the corresponding audiobook and analysed in terms of the two acoustic features under discussion. Typical values of SPL and the SD of SPL for different readers were measured in the entire chapters from which fragments were selected and the results were compared with those obtained from the extracts. In this way, it was possible to establish the relative shifts of SPL and the SD of SPL for each of the analysed fragments.

Contrary to what had been expected, a statistical analysis of the results revealed no effects of the character's gender on any of the response variables. However, conclusions concerning secondary aims were more definitive. A general trend to decrease the SD of SPL in dialogues in comparison to the rest of the text in a novel was observed. This tendency is independent of any of the factors included in the study. It was also observed that male American readers tend to lower their voice intensity when reading dialogues. All these findings may be applied in developing text to speech software.
\end{abstract}

Keywords: voice intensity; sound pressure level; gender in language; sex in language.

* Institute of Foreign Languages, Jan Kochanowski University in Kielce, ul. Świętokrzyska 21D, 25-406 Kielce, Poland, e-mail: lukasz.stolarski@ujk.edu.pl 


\section{Aims}

When text to speech (TTS) software is used to read informative passages, the resulting quality of the synthesised voice is frequently satisfactory. Nevertheless, listener satisfaction declines when TTS programs read e-books. The rendered voice is monotonous and lacks many of the emotive characteristics typical of the audiobooks read by human beings. This points to the need for more research into the acoustic characteristics of human voices when reading novels aloud.

The major aim of this project is to examine the effects of the literary character's gender on the reader's SPL and the SD of SPL. From the discussion summarised in Section 2, one may hypothesize that the values of the acoustic features will be higher for fragments of dialogues with male characters than with female characters. It must be stressed, however, that the analysis presented in Section 4.2 does not deal with the actual differences in SPL or the SD of SPL between the two sexes. Instead, it examines the implementation of these acoustic characteristics in rendering the character's gender by the reader (see the discussion in Section 5).

Secondary aims include examining general shifts of intensity and variability of intensity in dialogues independently from any confounding variables. Moreover, the effects of the reader's gender and the reader's dialect are also commented on. The database compiled for researching the major hypothesis outlined above is also suitable for exploring these additional tasks, all of which may be of value to TTS software developers.

\section{Background}

The speaker's gender is an important factor that affects numerous acoustic aspects of speech. It is frequently suggested that the major feature distinguishing the female voice from the male voice is the higher fundamental frequency (Abdulla \& Kasabov 2001; Fitzsimons, Sheahan \& Staunton 2001; Jung et al. 2002; Ohara 2003; Gelfer \& Mikos 2005; Yuasa 2008; Hu, Wu \& Nucci 2012; Latinus \& Taylor 2012; Machado et al. 2012). Moreover, it has been suggested that when compared to men, women speak with more 'breathiness' (Henton \& Bladon 1985; Klatt 1987; Holmberg, Hillman \& Perkell 1988; Klatt \& Klatt 1990; Mendoza et al. 1996), exhibit a slower speaking rate (Fichtelius, Johansson \& Nordin 1980; Klatt \& Klatt 1990; Byrd 1992; Whiteside 1996; Yuan, Liberman \& Cieri 2006; Verhoeven, De Pauw \& Kloots 2004; Quené 2008), have a higher average air flow (Sulter et al. 1994), make a greater number of pauses (Whiteside 1996), or demonstrate lower voice intensity. Since the last of these features is the central focus of this project, it requires further elaboration. 
The term 'intensity' as a descriptor of voice is used in a number of ways. Firstly, the word is applied when discussing measurements in watts per square metre $\left(\mathrm{W} / \mathrm{m}^{2}\right)$, as opposed to measurements in decibels $(\mathrm{dB})$; these are referred to as 'sound pressure level' (SPL) or 'intensity level' (Schötz 2006: 10). Following a common practice in phonetics, the word is used in this paper in the sense of the two latter notions. Secondly, the term is used to label measures such as 'available intensity range', 'conversational intensity level', or 'conversational intensity range' (Schmidt et al. 1990; Gelfer \& Young 1997). Because of such a diversity of notions associated with the name 'intensity', the values investigated in the present project are explicitly defined in Section 3. In short, the word is used to refer to the reader's average voice intensity measured in $\mathrm{dB}$ in a given audio recording and all other values presented in the paper are derived from this basic statistic.

A number of studies have indicated that there is a tendency for the female voice to involve lower intensity, but each used different methods. For instance, Childers \& Wu (1991) report lower average vowel amplitudes for F2, F3, and F4 in the female voice, and Susser \& Bless (1983) show higher SPL in the articulation of the vowel /a/ by boys than girls. Studies examining voice intensity in a more general way include Gelfer \& Young (1997), who observed that the conversational intensity level is $2 \mathrm{~dB}$ lower for women than for men and emphasise that this difference is statistically significant. Similarly, lower intensity in the female voice is reported by Terasawa, Kakita \& Hirano (1984) and Boren, Roginska \& Gill (2013). Differences between the two genders are also mentioned by Coleman, Mabis \& Hinson (1977), but these authors do not treat such variations as relevant. Finally, Kent \& Read (1992) list SPL as one of the major acoustic aspects distinguishing the male voice from the female voice, but they do not provide any evidence for this themselves, nor do they cite works by other researchers.

A few publications suggest that the speaker's gender does not affect voice intensity. Ptacek et al. (1966) provide data on the articulation of the vowel /a/ and do not indicate any clear tendencies for SPL to be higher for men than for women. Likewise, the analysis of a prolonged production of /a/ in Huber et al. (1999) reveal no consistent differences between the levels of intensity measured for male and female participants. Moreover, Hwa Chen (2006) found no effects of gender on speaking intensity among Mandarin Chinese speakers when reading sentences.

It is worth mentioning that one may also find indirect suggestions that the level of voice intensity may actually be higher for women than men. Hwa Chen reports that in voice range profiles "the intensity variables of the soft and the loud voice for the female group were significantly greater than those for the male group" (2006: 4) and Sulter, Schutte \& Miller (1996) observed larger 
amplitudes of the excursions of the vocal folds during vibration, which are correlated with an increase in sound intensity, for female subjects. Nevertheless, the overall assumption that results from this discussion is that voice intensity may be greater for male speakers than for female speakers. Alternatively, the category of gender may not affect this acoustic feature in a significant way, although such a conclusion would be based on a relatively smaller number of reports.

As far as the variability of voice intensity is concerned, there are indications that it may also be higher for men than for women. For instance, Coleman, Mabis \& Hinson (1977) reported that both 'greatest SPL range' and 'mean SPL range' are higher for male participants than for female participants, although these differences are not interpreted as important and the results were summarised as 'similar' in that paper. Likewise, the results obtained in Boren, Roginska \& Gill (2013) indicate a larger dynamic range for men, but the sample used is too small to confirm that the difference is statistically relevant. The higher values of the SPL range for male speakers observed in Gelfer \& Young (1997) are, however, statistically significant $(F=6.788, p=0.011)$.

It is important to emphasize that the studies discussed above report the range of intensity which indicates a possible degree of variability of the acoustic feature under analysis. Still, in the present paper the variability is measured as the standard deviation of SPL (the SD of SPL). This statistic reflects the variability of intensity in a much more reliable way; range only takes into account the two extreme values in a given data set. The effects of the speaker's gender on the standard deviation of SPL were reported by Ptacek et al. (1966), who indicated that men speak with a greater variability of intensity than women do.

\section{Methods}

The dependent variables used in this study include the reader's voice intensity measured in $\mathrm{dB}$, which is an acoustic correlate of vocal loudness (Gelfer \& Young 1997), and the variability of voice intensity calculated as the standard deviation of intensity measured in $\mathrm{dB}$. The major independent variable is the literary character's gender. The other two factors, the reader's gender and the reader's dialect, are included in the study primarily because they need to be controlled for. Both may have potential effects on the voice characteristics under discussion (see the discussion in Section 5).

In order to achieve the aims outlined in Section 1, the materials selected for the analysis need to meet specific criteria. The texts had to be fragments of dialogues uttered by either male or female characters in novels. The total sample had to be large enough for the results to be statistically relevant and as balanced as possible in terms of confounding variables. The sample of dialogue fragments 
used in Stolarski (2017) satisfies all of these criteria and is appropriate for the current project. The previous paper examined the way in which the character's gender affects the reader's fundamental frequency and prosodic explicitness. The process of selecting the appropriate materials for this task included gathering 32 fragments of dialogues involving male characters and 32 fragments of dialogues involving female characters. Both of these groups were balanced according to the reader's gender and dialect: each contained recordings by 16 male readers and 16 female readers, both of which included 8 speakers of American English and 8 speakers of British English. The excerpts were found with the use of AntConc (Anthony 2014) in various works by Charles Dickens downloaded as 'txt' files from the official web page of Project Gutenberg. The only exception was one excerpt involving a female character read by a female speaker of British English that was taken from Northanger Abbey by Jane Austin (see example 64 in Appendix B). The excerpts were taken from neutral contexts that did not provide any additional guidelines for reading the text. As discussed in Stolarski (2015), other factors, such as the emotions ascribed to a character in a given situation, may exert effects on the reader's voice. The fragments chosen for the analysis followed 'neutral' reporting verbs such as said or returned. Additionally, the cotext surrounding the chosen fragments did not suggest any particular way of reading the extract.

Measuring features such as voice intensity in a particular context poses the problem of speaker normalisation. Each reader has different voice characteristics and reporting absolute values in $\mathrm{Db}$ for a given fragment is not necessarily meaningful. Moreover, differences resulting from potentially dissimilar recording equipment and the distance of the microphone from the reader's mouth should also be controlled for. The statistical methods used in this study to handle these issues are consistent with those applied in Stolarski $(2015,2017)$. Namely, the solution chosen involves the use of paired tests. The SPL measured in a given fragment is compared to the 'typical' value of SPL for that reader and the difference obtained indicates whether the reader increased or decreased his/her voice intensity. Typical values were obtained by measuring the mean intensity in whole chapters from which the extracts were taken. The corresponding intensity values obtained in the excerpts were subtracted from these values. The same procedure was employed for measuring the SD of SPL and the resulting samples of differences (or shifts, as they are frequently referred to in this paper) were the focus of all the statistical tests summarised in Section 4. In fact, a one sample test performed on a set of such differences is equivalent to a paired test performed on the corresponding samples that are being compared. For the sake of simplicity, the description of the results in the following sections will concentrate on such samples of shifts rather than the individual data sets from which the differences were calculated. 
The alterations measured in $\mathrm{dB}$ were additionally converted into percentages. A similar shift measured in $\mathrm{dB}$ may have a different proportional value for different readers. For instance, the examples listed as 1,21 , and 50 in the Appendices are all similar in terms of the values provided in Column 15. In each of these cases, the shift of the SD of SPL is about 4.5 $\mathrm{dB}$. However, when the same values are calculated relative to the average SD of SPL for a given speaker, the results differ greatly. Example 1 involves a shift of about $37 \%$, example 21 a shift of about $28 \%$ and example 50 a shift of only $19 \%$. Expressing the results in percentage terms is an additional way of normalizing the results. Section 4 analyses both samples of differences reported in $\mathrm{dB}$ (Columns 11 and 15 in the Appendices) and in percentages (Columns 12 and 16 in the Appendices). By applying these measures, most of the possible confounding variables resulting from the reader's voice characteristics and different conditions in which the recordings were made were controlled for. It should be noted, however, that it is still possible that some additional factors had a minor influence on the results. For instance, no crucial variations in the general intensity level for each recording were detected, but it is not certain whether or not some readers changed their relative distance from the microphone while reading any of the fragments under analysis. Consequently, some results reported in Section 4 may have been affected by such movements, although it is very unlikely that such behaviour was frequent.

The audio materials used for this study were downloaded from www.librivox.org. Each chapter of the audiobooks was recorded as a separate $\mathrm{mp} 3$ file, which resolved the problem of the reader's fatigue as an additional confounding variable. The recordings did not involve any disruptive background noise which could have affected the measurements and their overall quality was appropriate for spoken English (the bit rate of the files was 64 or $128 \mathrm{kbit} / \mathrm{s}$ ). They were searched with the use of Audacity (Audacity Team 2014) and all the appropriate fragments were located. The acoustic analysis was carried out in Praat (Boersma \& Weenink 2014). The mean SPL and the SD of SPL were calculated for both excerpts and the corresponding chapters.

All the statistical tests in this study were performed with the use of the R 3.0.3 (R Development Core Team 2013)

Figure 1 displays the histograms of the major samples analysed in this paper. The graphs in the first row refer to the data investigated in Section 4.1 and the graphs in the second and third row present the data discussed in Section 4.2. It is plainly visible that most of the histograms are skewed to the left, which suggests that the data violate normality. This observation has been fully substantiated by the results of the Shapiro-Wilk test of normality provided inside each graph. All the p-values are clearly below the alpha level of 0.05 . 
Similar results have also been obtained for the samples analysed in Section 4.3. It is worth adding that an attempt to overcome this problem by applying 'log transformation' was unsuccessful. Consequently, non-parametric statistical methods were employed. The data discussed in Sections 4.1 and 4.2 were analysed with the use of the Wilcoxon signed-rank test. The only exception is the three-way ANOVA performed in Section 4.3. This test was chosen because it is necessary to investigate possible interactions between the character's gender and the other two factors specified earlier and there is no other available non-parametric counterpart. Still, the results discussed in Section 4.3 should be treated with caution.
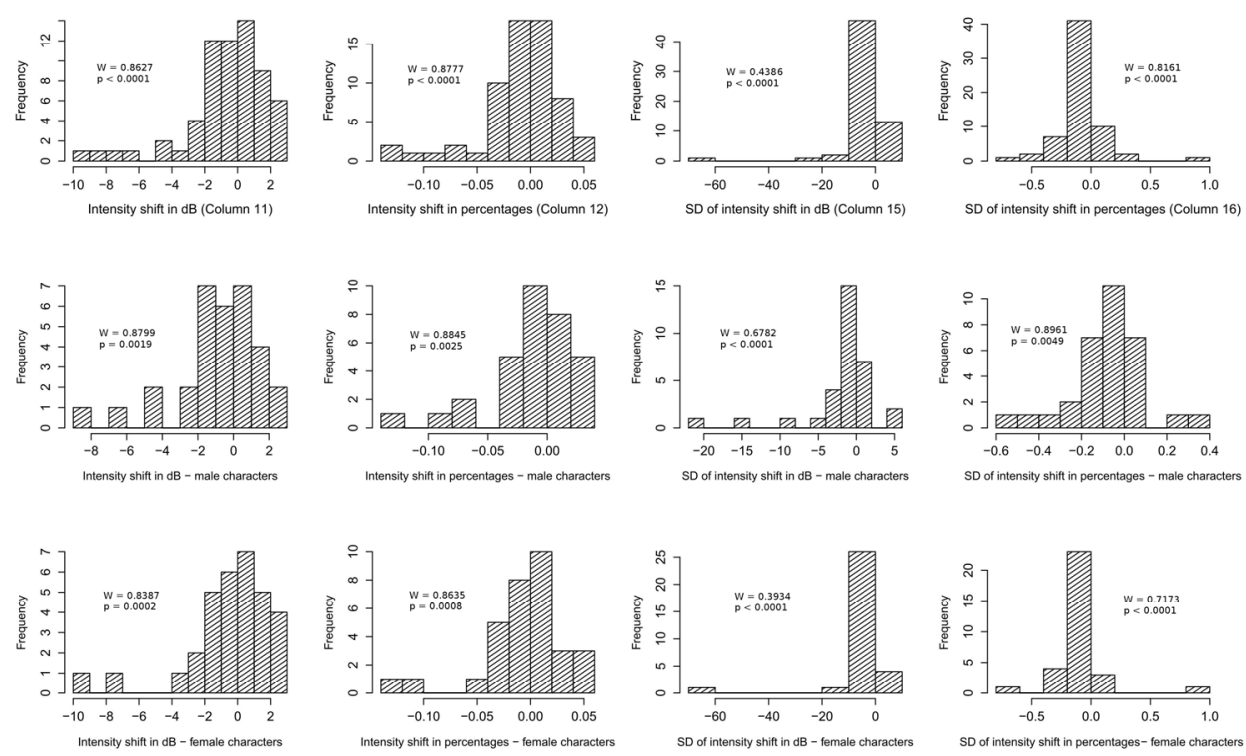

Figure 1: Histograms and the results of the corresponding Shapiro-Wilk tests of normality for the major samples analysed in Section 4

\section{Results}

This section is divided into three parts. The first one discusses shifts of intensity in the parts of dialogues listed in the appendices irrespective of any possible effects of the character's gender, the reader's gender or the reader's dialect. It is interesting to consider the general tendency of the reader's intensity values to change when reading dialogues. The second part investigates the effects of the literary character's gender on the response variables defined in Section 3. It is 
the most crucial part of the analysis because it addresses the main question raised in this paper. Finally, in Section 4.3 the effects of all the three explanatory variables are discussed.

\subsection{General shifts of SPL and the SD of SPL}

The samples of intensity shifts and SD of intensity shifts that are neither divided according to the literary character's gender nor the reader's gender/dialect come from Columns 11, 12, 15, and 16 of both Appendices. They are depicted in Figure 2.

It is immediately visible that the shifts of intensity measured in $\mathrm{dB}$, depicted in the upper left boxplot in Figure 2, are rather small. The distance between the first quartile and the last quartile is only $2.36 \mathrm{~dB}$ and the median is very close to $0(-0.235 \mathrm{~dB})$. The results of the Wilcoxon signed-rank test clearly show that this weak tendency for the readers to decrease their voice intensity is statistically insignificant $(\mathrm{V}=867, \mathrm{p}=0.2487)$. The same conclusions may be drawn from a visual inspection of the boxplot placed in the upper right-hand corner of Figure 2. The shifts of intensity expressed as percentages are also small and statistically insignificant (median $=-0.35 \%, \mathrm{~V}=866, \mathrm{p}=0.2459$ ).

The results concerning the two samples of the SD of intensity shifts are more revealing. Although the visual inspection of the boxplots presented in the lower part of Figure 2 does not suggest any obvious trends, the corresponding results of the Wilcoxon signed-rank test indicate statistically significant tendencies. The median of $-1.075 \mathrm{~dB}$ for the sample of shifts measured in $\mathrm{dB}$ (shown in the lower left boxplot in Figure 2) implies that the SD of the reader's SPL tends to decrease while reading dialogues. The result is statistically valid $(\mathrm{V}=316$, $\mathrm{p}<0.0001,95 \% \mathrm{CI}:-1.72 \mathrm{~dB},-0.78 \mathrm{~dB}$ ). The shifts measured in percentages (see the lower right boxplot in Figure 2) indicate the same tendency. The median for this sample is $-8.721 \%$ and this decrease in the variability of voice intensity should be treated as statistically significant $(\mathrm{V}=320, \mathrm{p}<0.0001,95 \%$ CI: $-11.02 \%,-5.36 \%)$. 


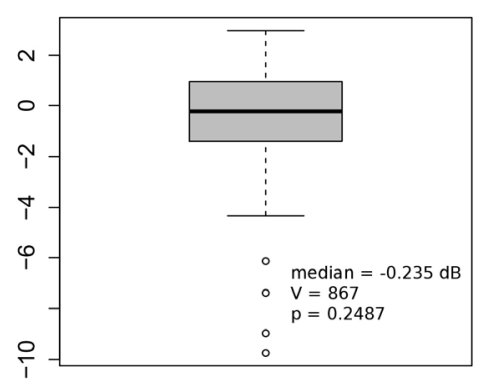

Intensity shifts in $\mathrm{dB}$ (Column 11)

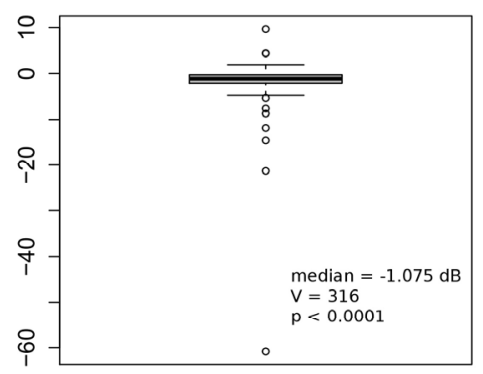

SD of intensity shifts in $\mathrm{dB}$ (Column 15)

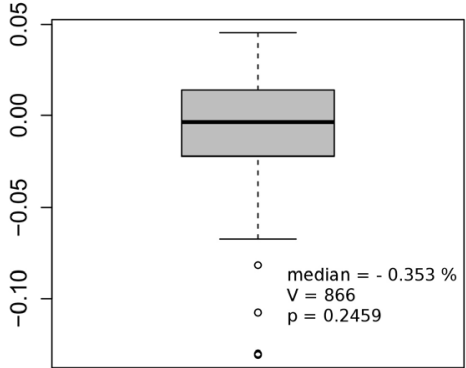

Intensity shifts in percentages (Column 12)

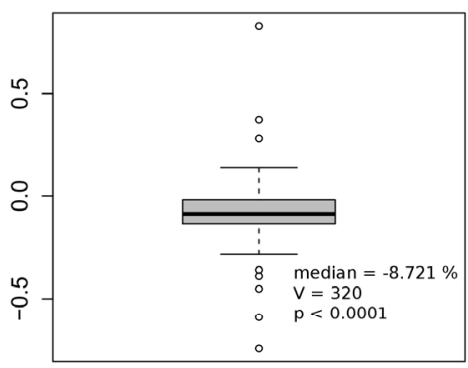

SD of intensity shifts in percentages (Column 16)

Figure 2: Boxplots showing the samples of general shifts of SPL and the SD of SPL in Columns 11, 12, 15 and 16 in the Appendices. The corresponding medians and the results of the Wilcoxon signed-rank test are provided inside the graphs. The size of each sample is 64 .

\subsection{Effects of the character's gender}

The shifts of intensity divided according to the character's gender are presented in the upper boxplots in Figure 3. The sample involving the shifts measured in $\mathrm{dB}$ in the dialogues with male characters is very similar to the one involving female characters. A small difference between the medians for the two samples may be observed, but it is statistically insignificant $(\mathrm{W}=571$, $\mathrm{p}$-value $=0.4322$, $95 \%$ CI: $-0.64 \mathrm{~dB}, 1.32 \mathrm{~dB}$ ). Neither are the medians under discussion significantly different from 0 . The one-sample Wilcoxon signed-rank test for the data set involving male characters yields $\mathrm{V}=194$ and $\mathrm{p}=0.1966$, and for the data set involving female characters $\mathrm{V}=252.5$ and $\mathrm{p}=0.837$. 
The intensity shifts divided according to the character's gender and expressed in percentages are depicted in the upper right-hand corner of Figure 3. The boxplots look almost identical to the previously discussed pair. The difference between the medians is very small and statistically insignificant $(\mathrm{W}=572, \mathrm{p}=0.4269,95 \%$ CI: $-0.94 \%, 1.98 \%)$. Likewise, there is not enough evidence to conclude that either of the two medians is different from 0 . The results of the one-sample Wilcoxon signed-rank test for the sample involving male characters are $\mathrm{V}=195$ and $\mathrm{p}=0.2032$, and for the sample involving female characters $\mathrm{V}=248$ and $\mathrm{p}=0.775$. To summarise, no effects of the character's gender on the reader's SPL were observed.

The results for the shifts of the SD of intensity are more complex. On the one hand, the Wilcoxon signed-rank test performed on individual samples of shifts divided according to the character's gender indicates that all the medians are statistically different from 0 (see the exact data provided besides the lower boxplots in Figure 3). These results add support to the conclusions reached in the last paragraph of Section 4.1. Even if the sample of the shifts of SD of intensity is split according to the character's gender, the decrease of the response variable is still statistically relevant. Nevertheless, this does not necessarily indicate any effects of the explanatory variable under discussion. A comparison of the shifts in the two groups measured in $\mathrm{dB}$ (depicted in the lower left-hand corner of Figure 3) yields non-significant results $(\mathrm{W}=417$, $\mathrm{p}$-value $=0.2045$, 95\% CI: $-1.37 \mathrm{~dB}, 0.34 \mathrm{~dB}$ ). The same conclusion should be drawn for the data expressed in percentages, shown graphically in the lower right-hand corner of Figure 3. Individually, the samples differ from 0 in a statistically significant way, but a comparison of the data sets reveals no significant difference $(\mathrm{W}=420$, p-value $=0.2209,95 \% \mathrm{CI}:-8.47 \%, 2.23)$. Consequently, no effects of the character's gender on the reader's SD of SPL were confirmed. 

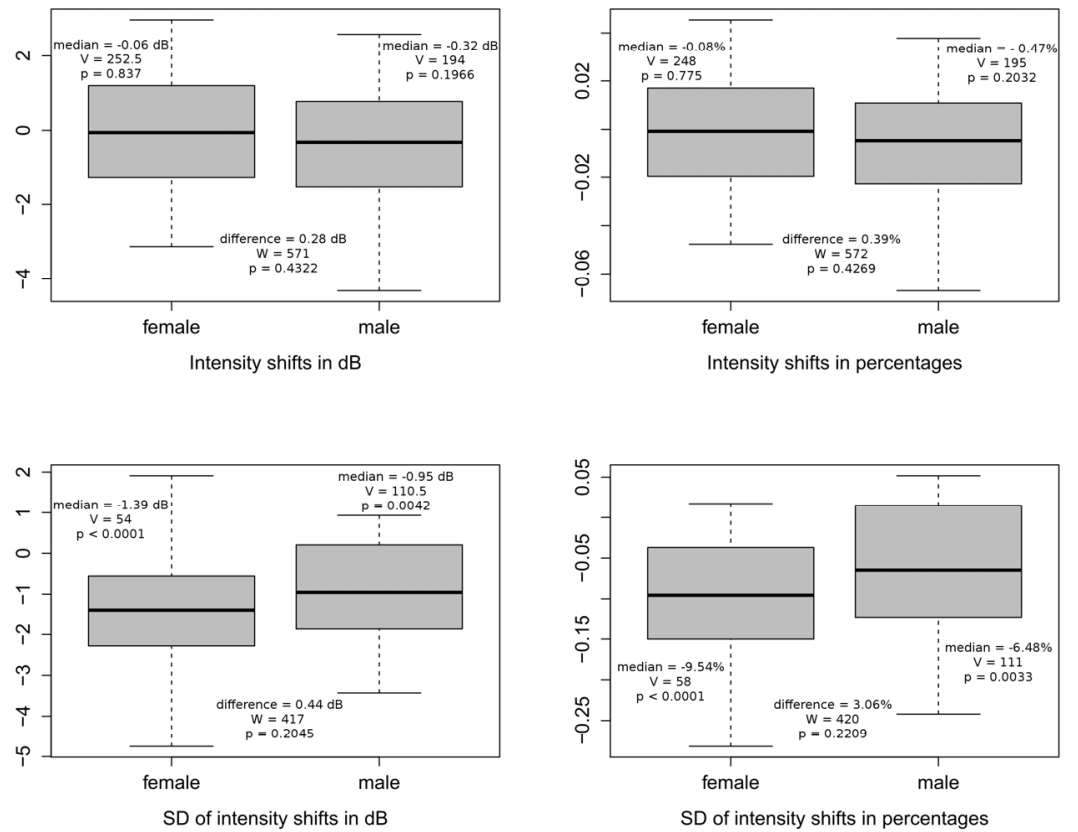

Figure 3: Shifts of SPL and the SD of SPL divided according to the character's gender. The results of the Wilcoxon signed-rank tests are provided inside the graphs. The size of each sample is 32 .

4.3. Effects of the character's gender, the reader's gender, and the reader's dialect - a three-way ANOVA analysis

For reasons of legibility and simplicity, the effects of all the independent variables will be discussed only in relation to shifts measured in terms of percentages (Column 12 for shifts of SPL and Column 16 for shifts of the SD of SPL in the Appendices). The corresponding tests performed on the shifts measured in $\mathrm{dB}$ yielded virtually identical results.

As indicated in Section 3, the samples listed in the Appendices, and many possible data sets obtained after dividing these samples according to any of the explanatory variables, violate the normality assumption. Consequently, nonparametric methods were used in Sections 4.1 and 4.2. In this part of the paper, however, the focus is on the simultaneous effects of all three independent variables and there are no convenient non-parametric methods to perform this task. Instead, a three-way ANOVA was used and even though some of the observations in this analysis were further tested with the use of the Wilcoxon 
signed-rank test, the results discussed below are only indications of possible trends rather than definitive findings.

Table 1 summarises the results of the ANOVA test comparing the effects of all the independent variables on the shifts in voice intensity that are listed in Column 12 in the Appendices. The high p-value for the character's gender coincides with the findings discussed in Section 4.2. This factor does not influence the reader's voice intensity in a statistically significant way. The other two explanatory variables, however, seem to have effects on the response variable. A closer analysis of the reader's gender reveals that male readers tend to decrease their voice intensity in the fragments cited in the Appendices (median $=-1.52 \%$ ). The results of the Wilcoxon signed-rank test confirms that this tendency is statistically relevant $(\mathrm{V}=150, \mathrm{p}=0.0324)$. Female readers, on the other hand, seem to slightly increase their voice intensity (median $=0.47 \%$ ), but this shift is statistically insignificant $(\mathrm{V}=316, \mathrm{p}=0.3402)$. Still, the difference between the two groups is relevant $(\mathrm{W}=676, \mathrm{p}=0.0274)$. A similar analysis of the effects of the reader's dialect indicates that American readers tend to decrease their voice intensity (median $=-1.56 \% \mathrm{~V}=129, \mathrm{p}=0.0105)$, while British readers do not (median $=0.87 \%, V=331, p=0.2168)$. Again, the difference between the groups is statistically significant $(\mathrm{W}=306$, $\mathrm{p}$-value $=0.0052$ ). Nonetheless, the result which is the most important in Table 1 is a possible interaction between the reader's gender and the reader's dialect $(p=0.0182)$. A closer inspection of this issue reveals that the decrease in voice intensity concerns exclusively American male readers (median $=-3.43 \%$, $\mathrm{V}=12, \mathrm{p}=0.0021,95 \% \mathrm{CI}:-7.04 \%,-1.59 \%)$. In the other groups, that is American female readers, British male readers and British female readers, the shifts are very small and statistically insignificant.

Table 1 Table 1: ANOVA table for intensity shifts measured in percentages as the response variable

\begin{tabular}{|c|c|c|c|c|c|}
\hline & Df & Sum Sq & Mean Sq & F value & $\operatorname{Pr}(>\mathbf{F})$ \\
\hline Character's gender & 1 & 0.00044 & 0.000437 & 0.427 & 0.5160 \\
\hline Reader's gender & 1 & 0.00739 & 0.007392 & 7.228 & $0.0094 * *$ \\
\hline Reader's dialect & 1 & 0.0123 & 0.012302 & 12.029 & $0.0010 * *$ \\
\hline Character's gender: Reader's gender & 1 & 0.00008 & 0.000083 & 0.082 & 0.7762 \\
\hline Character's gender: Reader's dialect & 1 & 0.00006 & 0.000055 & 0.054 & 0.8169 \\
\hline Reader's gender : Reader's dialect & 1 & 0.00605 & 0.006052 & 5.918 & $0.0182 *$ \\
\hline $\begin{array}{l}\text { Character's gender : Reader's gender : } \\
\text { Reader's dialect }\end{array}$ & 1 & 0.00016 & 0.000156 & 0.153 & 0.6976 \\
\hline Residuals & 56 & 0.05727 & 0.001023 & & \\
\hline \multicolumn{6}{|l|}{---} \\
\hline Signif. codes: 0 ‘***' 0.001 ' $* *$ ' $0.01^{\prime} *$ & . & & & & \\
\hline
\end{tabular}


Table 2 presents the results of the ANOVA examining the effects of all the factors on the shifts of SD of intensity measured in percentage terms. None of the explanatory variables has an effect on the response variable. The marginally significant score for the reader's dialect $(0.0762)$ has not been substantiated by the additional Wilcoxon signed-rank test $(\mathrm{W}=546, \mathrm{p}=0.655,95 \% \mathrm{CI}:-4.1 \%$, $7.93 \%$ ) and the factor cannot be assumed to influence the reader's variability of SPL. Moreover, none of the combinations of factors yielded p-values close to 0.05 , so no interactions were found, either.

Table 2. ANOVA table for the shifts of SD of intensity measured in percentages as the response variable

\begin{tabular}{|c|c|c|c|c|c|}
\hline & Df & Sum Sq & Mean Sq & F value & $\operatorname{Pr}(>\mathbf{F})$ \\
\hline Character's gender & 1 & 0.0037 & 0.00371 & 0.089 & 0.7663 \\
\hline Reader's gender & 1 & 0.0027 & 0.00274 & 0.066 & 0.7983 \\
\hline Reader's dialect & 1 & 0.1358 & 0.13584 & 3.263 & 0.0762 \\
\hline Character's gender : Reader's gender & 1 & 0.0081 & 0.00811 & 0.195 & 0.6606 \\
\hline Character's gender: Reader's dialect & 1 & 0.0005 & 0.00052 & 0.013 & 0.9113 \\
\hline Reader's gender : Reader's dialect & 1 & 0.0397 & 0.03974 & 0.955 & 0.3327 \\
\hline $\begin{array}{l}\text { Character's gender : Reader's gender: } \\
\text { Reader's dialect }\end{array}$ & 1 & 0.0175 & 0.01755 & 0.422 & 0.5188 \\
\hline Residuals & 56 & 2.331 & 0.04163 & & \\
\hline \multicolumn{6}{|l|}{---} \\
\hline Signif. codes: 0 ‘***, 0.001 '**, 0.01 ‘* & 5 ' & ، 1 & & & \\
\hline
\end{tabular}

\section{Conclusions}

The analysis reported in Section 4.2 focused on the major aim of the present project. It investigated the possible effects of a literary character's gender on the reader's SPL and SD of SPL. The results persistently showed that this independent variable does not affect any of the dependent variables. It must be stressed, however, that such findings do not disprove any possible differences between the values of voice intensity and variability of voice intensity in the speech of men and women. The analysis described in Section 4.2 was not designed in a way that would justify such a conclusion. Instead, there are two other possible interpretations of the results. Firstly, regardless of whether or not the differences really exist, the readers may be unaware of potential dissimilarities in intensity between the male voice and the female voice. As a result, they render the speech of men and women without adjusting either the voice intensity level, or the variability of voice intensity. Secondly, the readers may actually recognize potential differences in SPL and the SD of SPL typical for men and women, but they may regard such differences as not essential 
enough to be conveyed to the hearer. The readers may prioritize other phonetic features in distinguishing the two sexes, or even consider the gender distinction less crucial than other factors. This interpretation is consistent with the results reported in Stolarski $(2015,2017)$. Stolarski (2015) showed a strong tendency to signal the emotions of happiness and sadness in literary characters by changes in the reader's pitch. Stolarski (2017), on the other hand, found that the shifts in the reader's voice pitch are very weakly correlated with the character's gender. Therefore, readers may consider the category of gender to be, relatively speaking, less important than other aspects, such as emotions.

The practical implication of these findings is that in adapting TTS software for use with novels, developers should not vary intensity depending on the literary character's sex. This does not necessarily concern cases in which a program attempts to imitate a 'dramatic' reading in which dialogues involving different characters are read by different people.

The supplementary conclusions reached in this study involve the fact that the variability of the reader's SPL tends to decrease in dialogues when compared to the rest of the novel. This is somewhat counterintuitive. One expects more variability in voice intensity in dialogues, as they likely communicate a wider range of attitudes and emotions and involve more punctuation than narrative descriptions. Nevertheless, the observation is statistically significant and TTS software developers should take it into account. In order to obtain a more human-like reading of fiction, the SD of voice intensity should be reduced in dialogues by about $8 \%$. Moreover, the present results indicate an approximately $3 \%$ decrease in the average intensity in dialogues read by male American readers. This observation may also be utilised in TTS applications when this dialect is being rendered.

In future research the results obtained in this paper may be verified on a control group of professional actors who are potentially more conscious of the way in which gender is conveyed phonetically than the amateur readers analysed in Section 4. If the outcome of such an analysis were similar to the present one, the second interpretation given above would also be corroborated. One could explain the closeness in the values of SPL and the SD of SPL when rendering male and female voices by claiming that such differences are not essential to the reading aloud of prose rather than argue that the readers are just not aware of these differences.

Other future projects may investigate the effects of the reader's dialect on the voice intensity in the reading aloud of fiction. It has been reported that languages may differ in terms of such phonetic features as the maximum range of speaking fundamental frequency (Chen 2005), the variability of speaking fundamental frequency (Yamazawa \& Hollien 1992) or the maximum range of speaking intensity (Chen 2005). Likewise, various studies have shown 
differences between dialects of the same language in terms of select phonetic features. For instance, it has been demonstrated that dialects of American English from the South involve a slower articulation rate than dialects used in other parts of the USA (Byrd 1994; Jacewicz et al. 2009) and similar differences have been found between some dialects of Dutch (Quené 2008). A possible next step is to examine the changes in voice intensity and variability of voice intensity in the reading aloud of prose as a function of the reader's dialect. Initially, one could compare Standard British English to General American English, since the two dialects are the default choices in TTS applications, but other English dialects could also be investigated at a later date.

\section{REFERENCES}

Abdulla, Waleed H. \& Nikola Kirilov Kasabov. 2001. Improving speech recognition performance through gender separation. In Proceedings of Artificial Neural Networks and Expert Systems International Conference (ANNES), 218-222. Dunedin, New Zeland.

Anthony, Laurence. 2014. AntConc (version 3.4.3w) [computer software]. Tokyo: Waseda University.

Audacity Team. 2014. Audacity(R): Free audio editor and recorder (version 2.0.5) [computer software].

Boersma, Paul \& David Weenink. 2014. Praat, a system for doing phonetics by computer (version 5.4.01) [computer software]. Amsterdam: University of Amsterdam.

Boren, Braxton, Agnieszka Roginska \& Brian Gill. 2013. Maximum averaged and peak levels of vocal sound pressure. In Audio Engineering Society Convention 135, 692-698. Audio Engineering Society.

Byrd, Dani. 1992. Preliminary results on speaker-dependent variation in the TIMIT database. The Journal of the Acoustical Society of America 92(1). 593-596. DOI: 10.1121/1.404271

Byrd, Dani. 1994. Relations of sex and dialect to reduction. Speech Communication 15(1-2). 39 54. DOI: 10.1016/0167-6393(94)90039-6

Chen, Sheng H. 2005. The effects of tones on speaking frequency and intensity ranges in Mandarin and Min dialects. The Journal of the Acoustical Society of America 117(5). 3225-3230. DOI: 10.1121/1.1872312

Childers, Donald G. \& Ke Wu. 1991. Gender recognition from speech. Part II: Fine analysis. The Journal of the Acoustical society of America 90(4). 1841-1856. DOI: 10.1121/1.401664

Coleman, Robert F., Janet Henn Mabis \& Joanne Kidd Hinson. 1977. Fundamental frequencysound pressure level profiles of adult male and female voices. Journal of Speech, Language, and Hearing Research 20(2). 197-204. DOI: 10.1044/jshr.2002.197

Fichtelius, Anna, Iréne Johansson \& Kerstin Nordin. 1980. Three investigations of sex-associated speech variation in day school. Women's Studies International Quarterly 3(2-3). 219225. DOI: $10.1016 / \mathrm{S} 0148-0685(80) 92218-6$

Fitzsimons, Mary, Noirin Sheahan \& Hugh Staunton. 2001. Gender and the integration of acoustic dimensions of prosody: Implications for clinical studies. Brain and Language 78(1). 94-108. DOI: 10.1006/brln.2000.2448 
Gelfer, Marylou Pausewang \& Shannon Ryan Young. 1997. Comparisons of intensity measures and their stability in male and female sneakers. Journal of Voice 11(2). 178-186. DOI: $10.1016 /$ S0892-1997(97)80076-8

Gelfer, Marylou Pausewang \& Victoria A. Mikos. 2005. The relative contributions of speaking fundamental frequency and formant frequencies to gender identification based on isolated vowels. Journal of Voice 19(4). 544-554. DOI: 10.1016/j.jvoice.2004.10.006

Henton, Caroline G. \& R. Anthony W. Bladon. 1985. Breathiness in normal female speech: Inefficiency versus desirability. Language \& Communication 5(3). 221-227. DOI: 10.1016/0271-5309(85)90012-6

Holmberg, Eva B., Robert E. Hillman \& Joseph S. Perkell. 1988. Glottal airflow and transglottal air pressure measurements for male and female speakers in soft, normal, and loud voice. The Journal of the Acoustical Society of America 84(2). 511-529. DOI: $10.1121 / 1.396829$

Huber, Jessica E., Elaine T. Stathopoulos, Gina M. Curione, Theresa A. Ash \& Kenneth Johnson. 1999. Formants of children, women, and men: The effects of vocal intensity variation. The Journal of the Acoustical Society of America 106(3). 1532-1542. DOI: $10.1121 / 1.427150$

Hu, Yakun, Dapeng Wu \& Antonio Nucci. 2012. Pitch-based gender identification with two-stage classification. Security and Communication Networks 5(2). 211-225. DOI: $10.1002 / \mathrm{sec} .308$

Hwa Chen, S. 2006. Sex differences in frequency and intensity in reading and voice range profiles for Taiwanese adult speakers. Folia Phoniatrica et Logopaedica 59(1). 1-9. DOI: $10.1159 / 000096545$

Jacewicz, Ewa, Robert A. Fox, Caitlin O’Neill \& Joseph Salmons. 2009. Articulation rate across dialect, age, and gender. Language Variation and Change 21(2). 233-256. DOI: 10.1017/S0954394509990093

Jung, E., A. Th. Schwarzbacher, K. Humphreys \& Bob Lawlor. 2002. Application of real-time AMDF pitch-detection in a voice gender normalisation system. In Proceedings of 7 th International Conference on Spoken Language Processing, 2521-2524.

Kent, Raymond D. \& Charles Read. 1992. The acoustic analysis of speech. San Diego, California: Singular Publishing Group.

Klatt, Dennis H. 1987. Acoustic correlates of breathiness: First harmonic amplitude, turbulence noise, and tracheal coupling. The Journal of the Acoustical Society of America 82(S1). S91. DOI: 10.1121/1.2025051

Klatt, Dennis H. \& Laura C. Klatt. 1990. Analysis, synthesis, and perception of voice quality variations among female and male talkers. The Journal of the Acoustical Society of America 87(2). 820-857. DOI: 10.1121/1.398894

Latinus, Marianne \& Margot J. Taylor. 2012. Discriminating male and female voices: Differentiating pitch and gender. Brain Topography 25(2). 194-204. DOI: 10.1007/s10548-011-0207-9

Machado, Sheron, Emília Duarte, Júlia Teles, Lara Reis \& Francisco Rebelo. 2012. Selection of a voice for a speech signal for personalized warnings: The effect of speaker's gender and voice pitch. Work 41. 3592-3598. DOI: 10.3233/WOR-2012-0670-3592

Mendoza, Elvira, Nieves Valencia, Juana Muñoz \& Humberto Trujillo. 1996. Differences in voice quality between men and women: Use of the long-term average spectrum (LTAS). Journal of Voice 10(1). 59-66. DOI: 10.1016/S0892-1997(96)80019-1 
Ohara, Yumiko. 2003. Performing gender through voice pitch: A cross-cultural analysis of Japanese and American English. In Ursula Pasero \& Friederike Braun (eds.), Wahrnehmung und Herstellung von Geschlecht, 105-116. Opladen/Wiesbaden: VS Verlag für Sozialwissenschaften. DOI: 10.1007/978-3-322-89014-6_8

Ptacek, Paul H., Eric K. Sander, Walter H. Maloney \& C. C. Roe Jackson. 1966. Phonatory and related changes with advanced age. Journal of Speech, Language, and Hearing Research 9(3). 353-360. DOI: 10.1044/jshr.0903.353

Quené, Hugo. 2008. Multilevel modeling of between-speaker and within-speaker variation in spontaneous speech tempo. The Journal of the Acoustical Society of America 123(2). 1104-1113. DOI: $10.1121 / 1.2821762$

R Development Core Team. 2013. R: A language and environment for statistical computing (version 3.0.3) [computer software]. Vienna, Austria.

Schmidt, Charles P., Marylou Pausewang Gelfer \& Moya L. Andrews. 1990. Intensity range as a function of task and training. Journal of Voice 4(1). 30-36. DOI: 10.1016/S08921997(05)80079-7

Schötz, Susanne. 2006. Perception, analysis and synthesis of speaker age. Lund: Lund University Press.

Stolarski, Łukasz. 2015. Pitch patterns in vocal expression of "happiness" and "sadness" in the reading aloud of prose on the basis of selected audiobooks. Research in Language 13(2). 141-162. DOI: 10.1515/rela-2015-0016

Stolarski, Łukasz. 2017. Rendering of gender when reading fiction aloud. Linguistica Silesiana 38. 249-283.

Sulter, Arend M., Harm K. Schutte \& Donald G. Miller. 1996. Standardized laryngeal videostroboscopic rating: Differences between untrained and trained male and female subjects, and effects of varying sound intensity, fundamental frequency, and age. Journal of Voice 10(2). 175-189. DOI: 10.1016/S0892-1997(96)80045-2

Sulter, Arend M., Hero P. Wit, Harm K. Schutte \& Donald G. Miller. 1994. A structured approach to voice range profile (phonetogram) analysis. Journal of Speech, Language, and Hearing Research 37(5). 1076-1085. DOI: 10.1044/jshr.3705.1076

Susser, Robin D. \& D. M. Bless. 1983. Vocal intensity levels of normal and voice-disordered children. (Proceedings of the XIX Congress of the International Association of Logopedics and Phoniatrics).

Terasawa, Ruriko, Yuki Kakita \& Minoru Hirano. 1984. Simultaneous measurements of mean air flow rate, fundamental frequency and voice intensity. The Japan Journal of Logopedics and Phoniatrics 25(3). 189-207. DOI: 10.5112/jjlp.25.189

Verhoeven, Jo, Guy De Pauw \& Hanne Kloots. 2004. Speech rate in a pluricentric language: A comparison between Dutch in Belgium and the Netherlands. Language and Speech 47(3). 297-308. DOI: 10.1177/00238309040470030401

Whiteside, Sandra P. 1996. Temporal-based acoustic-phonetic patterns in read speech: Some evidence for speaker sex differences. Journal of the International Phonetic Association 26(1). 23-40. DOI: 10.1017/S0025100300005302

Yamazawa, Hideko \& Harry Hollien. 1992. Speaking fundamental frequency patterns of Japanese women. Phonetica 49(2). 128-140. DOI: 10.1159/000261907

Yuan, Jiahong, Mark Liberman \& Christopher Cieri. 2006. Towards an integrated understanding of speaking rate in conversation. In Proceedings of INTERSPEECH 2006, 541-544.

Yuasa, Ikuko Patricia. 2008. Culture and gender of voice pitch: A sociophonetic comparison of the Japanese and Americans. London, Oakville: Equinox Publishing. 


\section{Appendix A}

\begin{tabular}{|c|c|c|c|c|c|}
\hline $\begin{array}{c}\text { Example } \\
\text { number }\end{array}$ & Source & Extract & $\begin{array}{c}\text { Character's } \\
\text { name }\end{array}$ & $\begin{array}{c}\text { Character's } \\
\text { gender }\end{array}$ & $\begin{array}{c}\text { Reader's } \\
\text { initials }\end{array}$ \\
\hline 1 & $\begin{array}{l}\text { A Tale of } \\
\text { Two Cities. } \\
\text { Book } 2 \\
\text { Chapter } 4\end{array}$ & $\begin{array}{l}\text { "Nevertheless," pursued Darnay, rising to ring the bell, } \\
\text { "there is nothing in that, I hope, to prevent my calling the } \\
\text { reckoning, and our parting without ill-blood on either side." }\end{array}$ & $\begin{array}{l}\text { Charles } \\
\text { Darnay }\end{array}$ & male & B.F. \\
\hline 2 & $\begin{array}{l}\text { A Tale of } \\
\text { Two Cities. } \\
\text { Book } 2 \\
\text { Chapter } 4\end{array}$ & $\begin{array}{l}\text { "Nevertheless," pursued Darnay, rising to ring the bell, } \\
\text { "there is nothing in that, I hope, to prevent my calling the } \\
\text { reckoning, and our parting without ill-blood on either side." }\end{array}$ & $\begin{array}{l}\text { Charles } \\
\text { Darnay }\end{array}$ & male & P.A. \\
\hline 3 & $\begin{array}{l}\text { Our Mutual } \\
\text { Friend. } \\
\text { Book 1, } \\
\text { Chapter } 15\end{array}$ & $\begin{array}{l}\text { "Another staircase," said Mr Boffin, unlocking the door, } \\
\text { "leading down into the yard. We'll go down this way, as you } \\
\text { may like to see the yard, and it's all in the road. When the son } \\
\text { was a little child, it was up and down these stairs that he mostly } \\
\frac{\text { came and went to his father. He was very timid of his father. }}{\text { I've seen him sit on these stairs, in his shy way, poor child. }} \\
\text { many a time. Mr and Mrs Boffin have comforted him, sitting } \\
\text { with his little book on these stairs, often." }\end{array}$ & $\begin{array}{c}\text { Nicodemus } \\
\text { (Noddy) } \\
\text { Boffin }\end{array}$ & male & M. \\
\hline 4 & $\begin{array}{l}\text { Our Mutual } \\
\text { Friend. } \\
\text { Book 1, } \\
\text { Chapter } 15\end{array}$ & 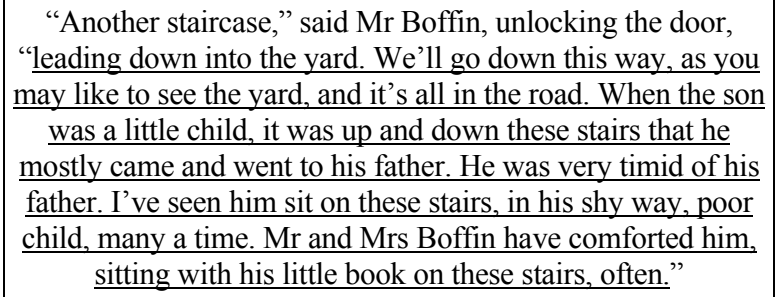 & $\begin{array}{c}\text { Nicodemus } \\
\text { (Noddy) } \\
\text { Boffin }\end{array}$ & male & D.J. \\
\hline 5 & $\begin{array}{l}\text { Little Doritt. } \\
\text { Book } 1 \\
\text { Chapter } 7\end{array}$ & $\begin{array}{l}\text { "Well, Amy, well. I don't quite follow you, but it's natural I } \\
\text { suppose that Fanny should prefer to be outside, and even that } \\
\text { you often should, too. So, you and Fanny and your uncle, my } \\
\frac{\text { dear, shall have your own way. Good, good. I'll not meddle; }}{\text { don't mind me." }}\end{array}$ & $\begin{array}{c}\text { William } \\
\text { Dorrit }\end{array}$ & male & E.C. \\
\hline 6 & $\begin{array}{l}\text { The } \\
\text { Haunted } \\
\text { Man and the } \\
\text { Ghost's } \\
\text { Bargain. } \\
\text { Chapter 1 }\end{array}$ & $\begin{array}{l}\text { "Spare me another moment, Philip. William, you were } \\
\text { going to tell me something to your excellent wife's honour. } \\
\text { It will not be disagreeable to her to hear you praise her." }\end{array}$ & $\begin{array}{c}\text { Professor } \\
\text { Redlaw }\end{array}$ & male & R.F. \\
\hline 7 & $\begin{array}{l}\text { The } \\
\text { Pickwick } \\
\text { Papers. } \\
\text { Chapter } 38\end{array}$ & $\begin{array}{l}\text { "No, no," said Mr. Ben Allen, laying aside the poker, and } \\
\text { looking very cunning; "I didn't think Wardle's exactly the } \\
\text { place for a headstrong girl; so, as I am her natural protector } \\
\text { and guardian, our parents being dead, I have brought her } \\
\text { down into this part of the country to spend a few months at } \\
\text { cun old aunt's, in a nice, dull, close place. I think that will } \\
\text { cure her, my boy. If it doesn't, I'll take her abroad for a little } \\
\text { while, and see what that'll do." }\end{array}$ & Ben Allen & male & S.E. \\
\hline
\end{tabular}




\begin{tabular}{|c|c|c|c|c|c|c|c|c|c|}
\hline $\begin{array}{l}\text { Reader's } \\
\text { gender }\end{array}$ & $\begin{array}{l}\text { Reader's } \\
\text { dialect }\end{array}$ & $\begin{array}{l}\text { Reader's } \\
\text { mean } \\
\text { intensity in } \\
\text { the whole } \\
\text { chapter in } \\
\text { dB }\end{array}$ & $\begin{array}{l}\text { Mean } \\
\text { intensity in } \\
\text { extract in } \\
\text { dB }\end{array}$ & $\begin{array}{c}\text { Shift of } \\
\text { intensity in } \\
\mathrm{dB}\end{array}$ & $\begin{array}{c}\text { Shift of } \\
\text { intensity in } \\
\text { percentages }\end{array}$ & $\begin{array}{l}\text { Reader's } \\
\text { SD of } \\
\text { intensity in } \\
\text { the whole } \\
\text { chapter in } \\
\text { dB }\end{array}$ & $\begin{array}{c}\mathrm{SD} \text { of } \\
\text { intensity in } \\
\text { extract in } \\
\mathrm{dB}\end{array}$ & $\begin{array}{l}\text { Shift of SD } \\
\text { of intensity } \\
\text { in } \mathrm{dB}\end{array}$ & $\begin{array}{l}\text { Shift of SD } \\
\text { of intensity } \\
\text { in } \\
\text { percentage }\end{array}$ \\
\hline male & $\mathrm{AmE}$ & 75,02 & 68,88 & $-6,14$ & $-8,18 \%$ & 11,69 & 16,06 & 4,37 & $37,38 \%$ \\
\hline male & $\mathrm{BrE}$ & 76 & 74,87 & $-1,13$ & $-1,49 \%$ & 12,03 & 10,55 & $-1,48$ & $-12,30 \%$ \\
\hline male & $\mathrm{AmE}$ & 64,38 & 61,9 & $-2,48$ & $-3,85 \%$ & 13,13 & 12,22 & $-0,91$ & $-6,93 \%$ \\
\hline male & $\mathrm{AmE}$ & 71,28 & 69,94 & $-1,34$ & $-1,88 \%$ & 12,4 & 11,34 & $-1,06$ & $-8,55 \%$ \\
\hline male & $\mathrm{BrE}$ & 76,79 & 77,62 & 0,83 & $1,08 \%$ & 22,39 & 22,87 & 0,48 & $2,14 \%$ \\
\hline male & AmE & 69,65 & 68,99 & $-0,66$ & $-0,95 \%$ & 20,25 & 19,88 & $-0,37$ & $-1,83 \%$ \\
\hline male & $\mathrm{BrE}$ & 68,27 & 70,85 & 2,58 & $3,78 \%$ & 14,42 & 14,67 & 0,25 & $1,73 \%$ \\
\hline
\end{tabular}




\begin{tabular}{|c|c|c|c|c|c|}
\hline $\begin{array}{c}\text { Example } \\
\text { number }\end{array}$ & Source & Extract & $\begin{array}{c}\text { Character's } \\
\text { name }\end{array}$ & $\begin{array}{c}\text { Character's } \\
\text { gender }\end{array}$ & $\begin{array}{c}\text { Reader's } \\
\text { initials }\end{array}$ \\
\hline 8 & $\begin{array}{c}\text { Oliver } \\
\text { Twist. } \\
\text { Chapter } 31\end{array}$ & $\begin{array}{l}\text { "The more I think of it," said the doctor, "the more I } \\
\text { see that it will occasion endless trouble and difficulty if } \\
\text { we put these men in possession of the boy's real story. I } \\
\text { am certain it will not be believed; and even if they can } \\
\text { do nothing to him in the end, still the dragging it } \\
\text { forward, and giving publicity to all the doubts that will } \\
\text { be cast upon it, must interfere, materially, with your } \\
\text { benevolent plan of rescuing him from misery." }\end{array}$ & \begin{tabular}{|} 
Mr. \\
Losberne \\
\end{tabular} & male & R.D. \\
\hline 9 & $\begin{array}{c}\text { Oliver } \\
\text { Twist. } \\
\text { Chapter } 2\end{array}$ & $\mid \begin{array}{l}\text { "I, Mrs. Mann. We name our fondlings in alphabetical } \\
\text { order. The last was a S,-S Swubble, I named him. This } \\
\text { was a T,-Twist, I named him. The next one comes } \\
\text { will be Unwin, and the next Vilkins. I have got names } \\
\text { ready made to the end of the alphabet, and all the way } \\
\text { through it again, when we come to Z." }\end{array}$ & $\begin{array}{c}\text { Mr. } \\
\text { Bumble }\end{array}$ & male & P.A. \\
\hline 10 & $\begin{array}{l}\text { Christmas } \\
\text { Carol. } \\
\text { Stave } 4\end{array}$ & $\begin{array}{l}\text { "And I know," said Bob, "I know, my dears, that when } \\
\text { we recollect how patient and how mild he was, although } \\
\text { he was a little, little child, we shall not quarrel easily } \\
\text { among ourselves, and forget poor Tiny Tim in doing it." }\end{array}$ & $\begin{array}{c}\text { Bob } \\
\text { Cratchit }\end{array}$ & male & J.F. \\
\hline 11 & $\begin{array}{l}\text { Christmas } \\
\text { Carol. } \\
\text { Stave } 4\end{array}$ & $\begin{array}{l}\text { "And I know," said Bob, "I know, my dears, that when } \\
\text { we recollect how patient and how mild he was, although } \\
\text { he was a little, little child, we shall not quarrel easily } \\
\text { among ourselves, and forget poor Tiny Tim in doing it." }\end{array}$ & $\begin{array}{c}\text { Bob } \\
\text { Cratchit }\end{array}$ & male & G.H. \\
\hline 12 & $\begin{array}{l}\text { Christmas } \\
\text { Carol. } \\
\text { Stave } 3\end{array}$ & $\begin{array}{l}\text { "As good as gold," said Bob, "and better. Somehow, } \\
\text { he gets thoughtful, sitting by himself so much, and } \\
\text { thinks the strangest things you ever heard. He told me, } \\
\text { coming home, that he hoped the people saw him in the } \\
\begin{array}{c}\text { church, because he was a cripple, and it might be } \\
\text { pleasant to them to remember upon Christmas-day }\end{array} \\
\text { who made lame beggars walk and blind men see." }\end{array}$ & $\begin{array}{c}\text { Bob } \\
\text { Cratchit }\end{array}$ & male & K.M. \\
\hline 13 & $\begin{array}{l}\text { Christmas } \\
\text { Carol. } \\
\text { Stave } 4\end{array}$ & $\begin{array}{l}\text { "And I know," said Bob, "I know, my dears, that } \\
\text { when we recollect how patient and how mild he was, } \\
\text { although he was a little, little child, we shall not } \\
\text { quarrel easily among ourselves, and forget poor Tiny } \\
\text { Tim in doing it." }\end{array}$ & $\begin{array}{c}\text { Bob } \\
\text { Cratchit }\end{array}$ & male & H.M. \\
\hline
\end{tabular}




\begin{tabular}{|c|c|c|c|c|c|c|c|c|c|}
\hline $\begin{array}{l}\text { Reader's } \\
\text { gender }\end{array}$ & $\begin{array}{c}\text { Reader's } \\
\text { dialect }\end{array}$ & $\begin{array}{l}\text { Reader's } \\
\text { mean } \\
\text { intensity in } \\
\text { the whole } \\
\text { chapter in } \\
\text { dB } \\
\end{array}$ & $\begin{array}{c}\text { Mean } \\
\text { intensity in } \\
\text { extract in } \\
\mathrm{dB}\end{array}$ & $\begin{array}{c}\text { Shift of } \\
\text { intensity in } \\
\text { dB }\end{array}$ & $\begin{array}{c}\text { Shift of } \\
\text { intensity in } \\
\text { percentages }\end{array}$ & $\begin{array}{l}\text { Reader's } \\
\text { SD of } \\
\text { intensity in } \\
\text { the whole } \\
\text { chapter in } \\
\text { dB }\end{array}$ & $\begin{array}{c}\text { SD of } \\
\text { intensity in } \\
\text { extract in } \\
\text { dB }\end{array}$ & $\begin{array}{l}\text { Shift of SD } \\
\text { of intensity } \\
\text { in dB }\end{array}$ & $\begin{array}{l}\text { Shift of SD } \\
\text { of intensity } \\
\text { in } \\
\text { percentages }\end{array}$ \\
\hline male & $\mathrm{BrE}$ & 66,66 & 65,62 & $-1,04$ & $-1,56 \%$ & 36,17 & 14,8 & $-21,37$ & $-59,08 \%$ \\
\hline male & $\mathrm{BrE}$ & 65,84 & 66,86 & 1,02 & $1,55 \%$ & 15,82 & 16,51 & 0,69 & $4,36 \%$ \\
\hline male & $\mathrm{AmE}$ & 69,97 & 68,32 & $-1,65$ & $-2,36 \%$ & 14,45 & 12,77 & $-1,68$ & $-11,63 \%$ \\
\hline male & $\mathrm{AmE}$ & 68,72 & 59,75 & $-8,97$ & $-13,05 \%$ & 14,17 & 10,74 & $-3,43$ & $-24,21 \%$ \\
\hline male & $\mathrm{AmE}$ & 68,18 & 68,04 & $-0,14$ & $-0,21 \%$ & 17,38 & 18,1 & 0,72 & $4,14 \%$ \\
\hline male & $\mathrm{AmE}$ & 65,65 & 61,48 & $-4,17$ & $-6,35 \%$ & 11,97 & 10,54 & $-1,43$ & $-11,95 \%$ \\
\hline
\end{tabular}




\begin{tabular}{|c|c|c|c|c|c|}
\hline $\begin{array}{c}\text { Example } \\
\text { number }\end{array}$ & Source & Extract & $\begin{array}{c}\text { Character's } \\
\text { name }\end{array}$ & $\begin{array}{c}\text { Character's } \\
\text { gender }\end{array}$ & $\begin{array}{c}\text { Reader' } \\
\text { initials }\end{array}$ \\
\hline 14 & $\begin{array}{c}\text { Life and } \\
\text { Adventures } \\
\text { of Martin } \\
\text { Chuzzlewit. } \\
\text { Chapter } 2\end{array}$ & $\begin{array}{l}\text { "Ye-es, a youth," said Mr Pecksniff. "He will avail } \\
\text { himself of the eligible opportunity which now offers, } \\
\quad \text { for uniting the advantages of the best practical } \\
\text { architectural education with the comforts of a home, } \\
\text { and the constant association with some who (however } \\
\text { humble their sphere, and limited their capacity) are } \\
\text { not unmindful of their moral responsibilities." }\end{array}$ & $\begin{array}{c}\text { Seth } \\
\text { Pecksniff }\end{array}$ & male & P.K. \\
\hline 15 & $\begin{array}{c}\text { The } \\
\text { Mistery of } \\
\text { Edwin } \\
\text { Drood. } \\
\text { Chapter } 6\end{array}$ & $\begin{array}{l}\text { "I am sure you will agree with me, Ma," said Mr. } \\
\text { Crisparkle, after thinking the matter over, "that the first } \\
\text { thing to be done, is, to put these young people as much } \\
\text { at their ease as possible. There is nothing disinterested in } \\
\text { the notion, because we cannot be at our ease with them } \\
\text { unless they are at their ease with us. Now, Jasper's } \\
\text { nephew is down here at present; and like takes to like, } \\
\text { and youth takes to youth. He is a cordial young fellow, } \\
\text { and we will have him to meet the brother and sister at } \\
\text { dinner. That's three. We can't think of asking him, } \\
\text { without asking Jasper. That's four. Add Miss } \\
\text { Twinkleton and the fairy bride that is to be, and that's } \\
\text { six. Add our two selves, and that's eight." }\end{array}$ & $\begin{array}{l}\text { Septimus } \\
\text { Crisparkle }\end{array}$ & male & A.C. \\
\hline 16 & $\begin{array}{c}\text { A Tale of } \\
\text { Two Cities. } \\
\text { Book 1, } \\
\text { Chapter } 5\end{array}$ & $\begin{array}{l}\text { "Gentlemen," said her husband, who had kept his } \\
\text { bright eye observantly upon her, "good day. The } \\
\text { chamber, furnished bachelor-fashion, that you wished } \\
\text { to see, and were inquiring for when I stepped out, is } \\
\text { on the fifth floor. The doorway of the staircase gives } \\
\text { on the little courtyard close to the left here," }\end{array}$ & $\begin{array}{c}\text { Monsieur } \\
\text { Defarge }\end{array}$ & male & A.M. \\
\hline 17 & $\begin{array}{c}\text { Our } \\
\text { Mutual } \\
\text { Friend. } \\
\text { Book 1, } \\
\text { Chapter 15 }\end{array}$ & $\begin{array}{l}\text { "Another staircase," said Mr Boffin, unlocking the } \\
\text { door, "leading down into the yard. We'll go down this } \\
\text { way, as you may like to see the yard, and it's all in the } \\
\text { road. When the son was a little child, it was up and } \\
\text { down these stairs that he mostly came and went to his } \\
\text { father. He was very timid of his father. I've seen him } \\
\underline{\text { sit on these stairs, in his shy way, poor child, many a }} \\
\text { time. Mr and Mrs Boffin have comforted him, sitting } \\
\text { with his little book on these stairs, often." }\end{array}$ & $\begin{array}{c}\text { Nicodemus } \\
\text { (Noddy) } \\
\text { Boffin }\end{array}$ & male & M.N. \\
\hline
\end{tabular}




\begin{tabular}{|c|c|c|c|c|c|c|c|c|c|}
\hline $\begin{array}{l}\text { Reader's } \\
\text { gender }\end{array}$ & $\begin{array}{c}\text { Reader's } \\
\text { dialect }\end{array}$ & $\begin{array}{l}\text { Reader's } \\
\text { mean } \\
\text { intensity in } \\
\text { the whole } \\
\text { chapter in } \\
\text { dB } \\
\end{array}$ & $\begin{array}{c}\text { Mean } \\
\text { intensity in } \\
\text { extract in } \\
\text { dB }\end{array}$ & $\begin{array}{c}\text { Shift of } \\
\text { intensity in } \\
\mathrm{dB}\end{array}$ & $\begin{array}{c}\text { Shift of } \\
\text { intensity in } \\
\text { percentages }\end{array}$ & \begin{tabular}{|c|} 
Reader's \\
SD of \\
intensity in \\
the whole \\
chapter in \\
dB
\end{tabular} & $\begin{array}{c}\text { SD of } \\
\text { intensity in } \\
\text { extract in } \\
\text { dB }\end{array}$ & $\begin{array}{l}\text { Shift of SD } \\
\text { of intensity } \\
\text { in } \mathrm{dB}\end{array}$ & $\begin{array}{c}\text { Shift of SD } \\
\text { of intensity } \\
\text { in } \\
\text { percentages }\end{array}$ \\
\hline male & $\mathrm{BrE}$ & 67,29 & 66,01 & $-1,28$ & $-1,90 \%$ & 17,18 & 16,67 & $-0,51$ & $-2,97 \%$ \\
\hline male & $\mathrm{BrE}$ & 73,57 & 71,35 & $-2,22$ & $-3,02 \%$ & 14,22 & 14,06 & $-0,16$ & $-1,13 \%$ \\
\hline male & $\mathrm{BrE}$ & 68,63 & 69,63 & 1 & $1,46 \%$ & 22,37 & 13,68 & $-8,69$ & $-38,85 \%$ \\
\hline female & $\mathrm{BrE}$ & 70,22 & 69,89 & $-0,33$ & $-0,47 \%$ & 17,99 & 18,92 & 0,93 & $5,17 \%$ \\
\hline
\end{tabular}




\begin{tabular}{|c|c|c|c|c|c|}
\hline $\begin{array}{c}\text { Example } \\
\text { number }\end{array}$ & Source & Extract & $\begin{array}{c}\text { Character's } \\
\text { name }\end{array}$ & $\begin{array}{c}\text { Character's } \\
\text { gender }\end{array}$ & $\begin{array}{c}\text { Reader's } \\
\text { initials }\end{array}$ \\
\hline 18 & $\begin{array}{c}\text { Bleak } \\
\text { House. } \\
\text { Chapter } 6\end{array}$ & $\begin{array}{l}\text { "As to Skimpole," said Mr. Jarndyce, "a habitable } \\
\text { doll's house with good board and a few tin people to } \\
\text { get into debt with and borrow money of would set the } \\
\text { boy up in life. He is in a child's sleep by this time, I } \\
\text { suppose; it's time I should take my craftier head to my } \\
\text { more worldly pillow. Good night, my dears." }\end{array}$ & $\begin{array}{c}\text { John } \\
\text { Jarndyce }\end{array}$ & male & C.L. \\
\hline 19 & $\begin{array}{c}\text { The Haunted } \\
\text { Man and the } \\
\text { Ghost's } \\
\text { Bargain. } \\
\text { Chapter } 1\end{array}$ & $\begin{array}{l}\text { "Spare me another moment, Philip. William, you } \\
\text { were going to tell me something to your excellent } \\
\text { wife's honour. It will not be disagreeable to her to } \\
\text { hear you praise her." }\end{array}$ & $\begin{array}{c}\text { Professor } \\
\text { Redlaw }\end{array}$ & male & R.G. \\
\hline 20 & $\begin{array}{l}\text { The } \\
\text { Pickwick } \\
\text { Papers. } \\
\text { Chapter } 38\end{array}$ & $\begin{array}{l}\text { "No, no," said Mr. Ben Allen, laying aside the poker, and } \\
\text { looking very cunning; 'I didn't think Wardle's exactly } \\
\text { the place for a headstrong girl; so, as I am her natural } \\
\text { protector and guardian, our parents being dead, I have } \\
\text { brought her down into this part of the country to spend a } \\
\text { few months at an old aunt's, in a nice, dull, close place. I } \\
\underline{\text { think that will cure her, my boy. If it doesn't, I'll take her }} \\
\text { abroad for a little while, and see what that'll do." }\end{array}$ & Ben Allen & male & D.L. \\
\hline 21 & $\begin{array}{c}\text { Oliver } \\
\text { Twist. } \\
\text { Chapter } 2\end{array}$ & $\begin{array}{l}\text { "I, Mrs. Mann. We name our fondlings in alphabetical } \\
\text { order. The last was a S,-Swubble, I named him. This } \\
\text { was a T,-Twist, I named him. The next one comes will } \\
\text { be Unwin, and the next Vilkins. I have got names ready } \\
\frac{\text { made to the end of the alphabet, and all the way through }}{\text { it again, when we come to Z." }}\end{array}$ & $\begin{array}{c}\text { Mr. } \\
\text { Bumble }\end{array}$ & male & K.P. \\
\hline 22 & $\begin{array}{c}\text { Oliver } \\
\text { Twist. } \\
\text { Chapter } 36\end{array}$ & $\begin{array}{l}\text { "I hope I may have good cause to do so," replied Mr. } \\
\text { Losberne; "though I confess I don't think I shall. But } \\
\text { yesterday morning you had made up your mind, in a } \\
\text { great hurry, to stay here, and to accompany your } \\
\text { mother, like a dutiful son, to the sea-side. Before noon, } \\
\text { you announce that you are going to do me the honour of } \\
\underline{\text { accompanying me as far as I go, on your road to }} \\
\underline{\text { London. And at night, you urge me, with great mystery, }} \\
\underline{\text { to start before the ladies are stirring; the consequence of }} \\
\underline{\text { which is, that young Oliver here is pinned down to his }} \\
\underline{\text { breakfast when he ought to be ranging the meadows }} \\
\text { after botanical phenomena of all kinds." }\end{array}$ & $\begin{array}{c}\text { Mr. } \\
\text { Losberne }\end{array}$ & male & C.S. \\
\hline
\end{tabular}




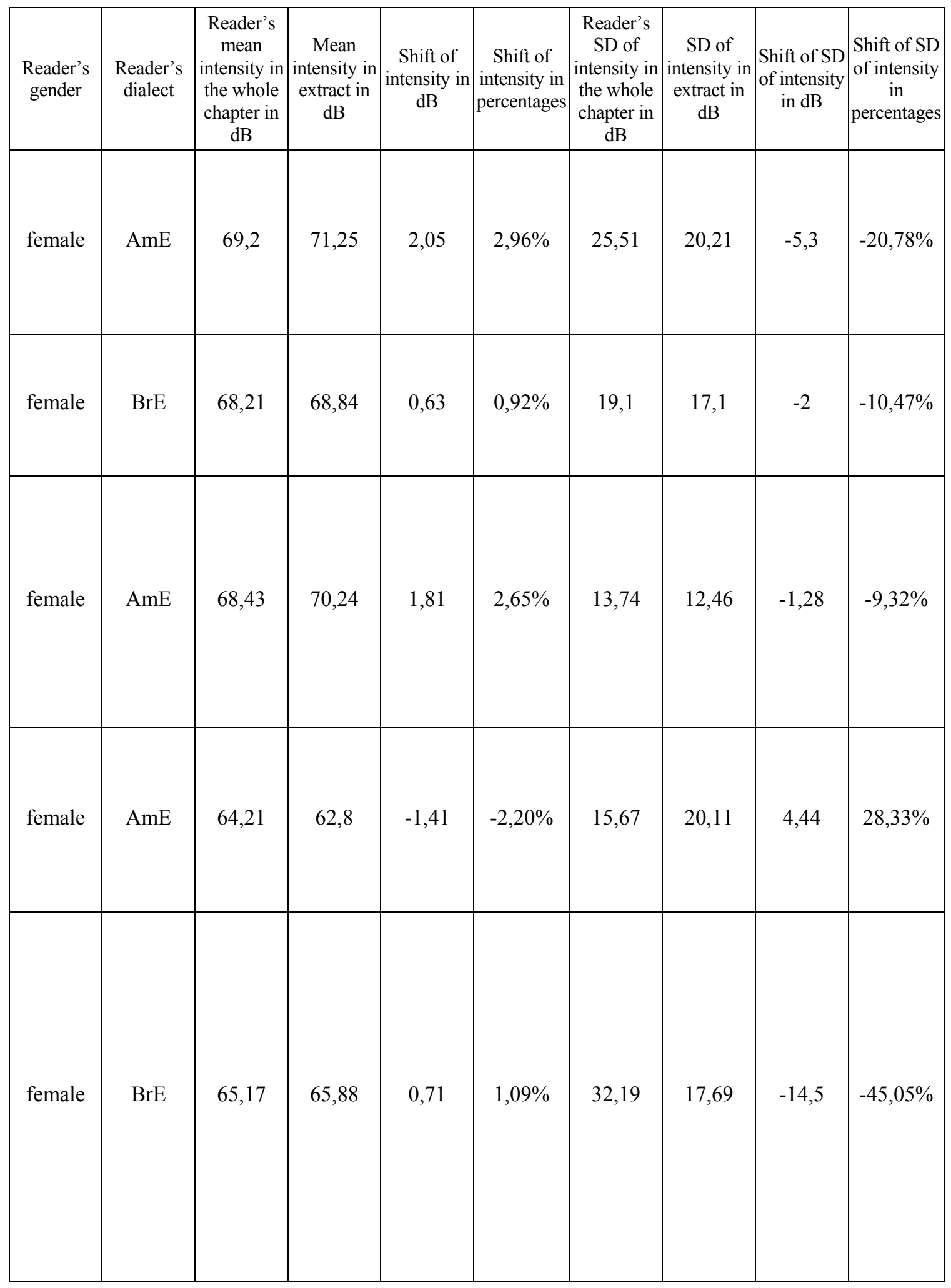




\begin{tabular}{|c|c|c|c|c|c|}
\hline $\begin{array}{c}\text { Example } \\
\text { number }\end{array}$ & Source & Extract & $\begin{array}{c}\text { Character's } \\
\text { name }\end{array}$ & $\mid \begin{array}{c}\text { Character's } \\
\text { gender }\end{array}$ & $\begin{array}{c}\text { Reader's } \\
\text { initials }\end{array}$ \\
\hline 23 & $\begin{array}{c}\text { David } \\
\text { Copperfield. } \\
\text { Chapter } 4\end{array}$ & $\begin{array}{l}\text { "Jane Murdstone," said Mr. Murdstone to his sister, } \\
\text { "any harsh words between us are, I hope, uncommon. } \\
\frac{\text { It is not my fault that so unusual an occurrence has }}{\text { taken place tonight. I was betrayed into it by another. }} \\
\frac{\text { Nor is it your fault. You were betrayed into it by }}{\text { another. Let us both try to forget it." }}\end{array}$ & $\begin{array}{l}\text { Edward } \\
\text { Murdstone }\end{array}$ & male & L.A. \\
\hline 24 & $\begin{array}{c}\text { Christmas } \\
\text { Carol. } \\
\text { Stave } 3\end{array}$ & $\begin{array}{l}\text { "As good as gold," said Bob, "and better. Somehow, } \\
\text { he gets thoughtful, sitting by himself so much, and } \\
\text { thinks the strangest things you ever heard. He told } \\
\text { me, coming home, that he hoped the people saw him } \\
\text { in the church, because he was a cripple, and it might } \\
\text { be pleasant to them to remember upon Christmas-day } \\
\text { who made lame beggars walk and blind men see." }\end{array}$ & $\begin{array}{c}\text { Bob } \\
\text { Cratchit }\end{array}$ & male & K.S. \\
\hline 25 & $\begin{array}{c}\text { The Old } \\
\text { Curiosity } \\
\text { Shop. } \\
\text { Chapter } 7\end{array}$ & $\begin{array}{l}\text { "Why, Mr Trent," returned Dick, "there is a proverb } \\
\text { which talks about being merry and wise. There are } \\
\text { some people who can be merry and can't be wise, } \\
\text { and some who can be wise (or think they can) and } \\
\text { can't be merry. I'm one of the first sort. If the } \\
\text { proverb's a good 'un, I suppose it's better to keep to } \\
\text { half of it than none; at all events, I'd rather be merry } \\
\text { and not wise, than like you, neither one nor t'other." }\end{array}$ & $\begin{array}{l}\text { Richard } \\
\text { 'Dick' } \\
\text { Swiveller } \\
\end{array}$ & male & E. \\
\hline 26 & $\begin{array}{c}\text { A Tale of } \\
\text { Two Cities. } \\
\text { Book 2, } \\
\text { Chapter } 6\end{array}$ & $\begin{array}{l}\text { "True," said he, "and fearful to reflect upon. Yet, a } \\
\text { doubt lurks in my mind, Miss Pross, whether it is } \\
\text { good for Doctor Manette to have that suppression } \\
\text { always shut up within him. Indeed, it is this doubt } \\
\text { and the uneasiness it sometimes causes me that has } \\
\text { led me to our present confidence." }\end{array}$ & $\begin{array}{l}\text { Jarvis } \\
\text { Lorry }\end{array}$ & male & T. \\
\hline 27 & $\begin{array}{c}\text { Our Mutual } \\
\text { Friend. } \\
\text { Book 1, } \\
\text { Chapter 1 }\end{array}$ & $\begin{array}{c}\text { "How can you be so thankless to your best friend, } \\
\text { Lizzie? The very fire that warmed you when you } \\
\text { were a babby, was picked out of the river alongside } \\
\text { the coal barges. The very basket that you slept in, the } \\
\text { tide washed ashore. The very rockers that I put it } \\
\text { upon to make a cradle of it, I cut out of a piece of } \\
\text { wood that drifted from some ship or another." }\end{array}$ & $\begin{array}{l}\text { Jesse } \\
\text { "Gaffer" } \\
\text { Hexam }\end{array}$ & male & O.D. \\
\hline
\end{tabular}




\begin{tabular}{|c|c|c|c|c|c|c|c|c|c|}
\hline $\begin{array}{l}\text { Reader's } \\
\text { gender }\end{array}$ & $\begin{array}{c}\text { Reader's } \\
\text { dialect }\end{array}$ & $\begin{array}{l}\text { Reader's } \\
\text { mean } \\
\text { intensity in } \\
\text { the whole } \\
\text { chapter in } \\
\text { dB }\end{array}$ & $\begin{array}{l}\text { Mean } \\
\text { intensity in } \\
\text { extract in } \\
\quad d B\end{array}$ & $\begin{array}{c}\text { Shift of } \\
\text { intensity in } \\
\mathrm{dB}\end{array}$ & $\begin{array}{c}\text { Shift of } \\
\text { intensity in } \\
\text { percentages }\end{array}$ & \begin{tabular}{|} 
Reader's \\
SD of \\
intensity in \\
the whole \\
chapter in \\
dB
\end{tabular} & $\begin{array}{c}\text { SD of } \\
\text { intensity in } \\
\text { extract in } \\
\text { dB }\end{array}$ & $\begin{array}{l}\text { Shift of SD } \\
\text { of intensity } \\
\text { in } \mathrm{dB}\end{array}$ & $\begin{array}{l}\text { Shift of SD } \\
\text { of intensity } \\
\text { in } \\
\text { percentages }\end{array}$ \\
\hline female & $\mathrm{AmE}$ & 64,44 & 60,12 & $-4,32$ & $-6,70 \%$ & 13,92 & 13,39 & $-0,53$ & $-3,81 \%$ \\
\hline female & AmE & 69,25 & 68,26 & $-0,99$ & $-1,43 \%$ & 16,66 & 14,48 & $-2,18$ & $-13,09 \%$ \\
\hline female & $\mathrm{BrE}$ & 74,64 & 75,25 & 0,61 & $0,82 \%$ & 16,6 & 15,6 & -1 & $-6,02 \%$ \\
\hline female & $\mathrm{AmE}$ & 66,96 & 66,7 & $-0,26$ & $-0,39 \%$ & 12,16 & 11,04 & $-1,12$ & $-9,21 \%$ \\
\hline female & $\mathrm{BrE}$ & 68,08 & 69,72 & 1,64 & $2,41 \%$ & 14,16 & 12,43 & $-1,73$ & $-12,22 \%$ \\
\hline
\end{tabular}




\begin{tabular}{|c|c|c|c|c|c|}
\hline $\begin{array}{c}\text { Example } \\
\text { number }\end{array}$ & Source & Extract & $\begin{array}{c}\text { Character's } \\
\text { name }\end{array}$ & $\begin{array}{c}\text { Character's } \\
\text { gender }\end{array}$ & $\begin{array}{c}\text { Reader's } \\
\text { initials }\end{array}$ \\
\hline 28 & $\begin{array}{l}\text { Our } \\
\text { Mutual } \\
\text { Friend. } \\
\text { Book 1, } \\
\text { Chapter 2 }\end{array}$ & $\begin{array}{l}\text { "We must now return, as novelists say, and as we all } \\
\text { wish they wouldn't, to the man from Somewhere. Being } \\
\text { a boy of fourteen, cheaply educated at Brussels when his } \\
\text { sister's expulsion befell, it was some little time before he } \\
\text { heard of it - probably from herself, for the mother was } \\
\text { dead; but that I don't know. Instantly, he absconded, and } \\
\text { came over here. He must have been a boy of spirit and } \\
\text { resource, to get here on a stopped allowance of five sous } \\
\text { a week; but he did it somehow, and he burst in on his } \\
\text { father, and pleaded his sister's cause. Venerable parent } \\
\text { promptly resorts to anathematization, and turns him out. } \\
\text { Shocked and terrified boy takes flight, seeks his fortune, } \\
\text { gets aboard ship, ultimately turns up on dry land among } \\
\text { the Cape wine: small proprietor, farmer, grower-二 } \\
\text { whatever you like to call it." }\end{array}$ & $\begin{array}{l}\text { Mortimer } \\
\text { Lightwood } \\
\\
\\
\end{array}$ & male & K.F. \\
\hline 29 & $\begin{array}{l}\text { Our } \\
\text { Mutual } \\
\text { Friend. } \\
\text { Book 1, } \\
\text { Chapter } 16\end{array}$ & $\begin{array}{l}\text { "No. But while I am in your employment, sir, I would } \\
\text { rather be excused from going between the lawyer and } \\
\text { the client. Of course if you press it, Mr Boffin, I am } \\
\text { ready to comply. But I should take it as a great favour } \\
\text { if you would not press it without urgent occasion." }\end{array}$ & $\begin{array}{l}\text { John } \\
\text { Rokesmith } \\
\text { (John } \\
\text { Harmon) }\end{array}$ & male & J.B. \\
\hline 30 & $\begin{array}{l}\text { Our } \\
\text { Mutual } \\
\text { Friend. } \\
\text { Book 2, } \\
\text { Chapter } 3\end{array}$ & $\begin{array}{l}\text { "My political opinions," says Veneering, not } \\
\text { previously aware of having any, "are identical with } \\
\text { those of Lord Snigsworth, and perhaps as a matter of } \\
\text { public feeling and public principle, Lord Snigsworth } \\
\text { would give me his name." }\end{array}$ & $\begin{array}{c}\text { Mr. } \\
\text { Veneering }\end{array}$ & male & R.N. \\
\hline 31 & $\begin{array}{c}\text { Oliver } \\
\text { Twist. } \\
\text { Chapter } 41\end{array}$ & $\begin{array}{l}\text { "Now, Miss Maylie," said Mr. Brownlow, "to return to } \\
\text { the subject in which your humanity is so much } \\
\text { interested. Will you let me know what intelligence you } \\
\text { have of this poor child: allowing me to promise that I } \\
\text { exhausted every means in my power of discovering him, } \\
\text { and that since I have been absent from this country, my } \\
\text { first impression that he had imposed upon me, and had } \\
\text { been persuaded by his former associates to rob me, has } \\
\text { been considerably shaken." }\end{array}$ & $\begin{array}{l}\text { Mr. } \\
\text { Brownlow }\end{array}$ & male & A.V. \\
\hline 32 & $\begin{array}{l}\text { The } \\
\text { Pickwick } \\
\text { Papers. } \\
\text { Chapter } 5\end{array}$ & $\begin{array}{l}\text { "Ah! people need to rise early, to see the sun in all his } \\
\text { splendour, for his brightness seldom lasts the day } \\
\text { through. The morning of day and the morning of life } \\
\text { are but too much alike." }\end{array}$ & $\begin{array}{c}\text { Samuel } \\
\text { Pickwick }\end{array}$ & male & V. \\
\hline
\end{tabular}




\begin{tabular}{|c|c|c|c|c|c|c|c|c|c|}
\hline $\begin{array}{l}\text { Reader's } \\
\text { gender }\end{array}$ & $\begin{array}{c}\text { Reader's } \\
\text { dialect }\end{array}$ & $\begin{array}{l}\text { Reader's } \\
\text { mean } \\
\text { intensity in } \\
\text { the whole } \\
\text { chapter in } \\
\text { dB } \\
\end{array}$ & $\begin{array}{c}\text { Mean } \\
\text { intensity in } \\
\text { extract in } \\
\text { dB }\end{array}$ & $\begin{array}{c}\text { Shift of } \\
\text { intensity in } \\
\mathrm{dB}\end{array}$ & $\begin{array}{c}\text { Shift of } \\
\text { intensity in } \\
\text { percentages }\end{array}$ & \begin{tabular}{|c|} 
Reader's \\
SD of \\
intensity in \\
the whole \\
chapter in \\
dB
\end{tabular} & $\begin{array}{c}\text { SD of } \\
\text { intensity in } \\
\text { extract in } \\
\text { dB }\end{array}$ & $\begin{array}{l}\text { Shift of SD } \\
\text { of intensity } \\
\text { in } \mathrm{dB}\end{array}$ & $\begin{array}{l}\text { Shift of SD } \\
\text { of intensity } \\
\text { in } \\
\text { percentages }\end{array}$ \\
\hline female & $\mathrm{AmE}$ & 59,46 & 59,95 & 0,49 & $0,82 \%$ & 9,22 & 9,4 & 0,18 & $1,95 \%$ \\
\hline female & $\mathrm{BrE}$ & 66,39 & 68,3 & 1,91 & $2,88 \%$ & 11,81 & 11,58 & $-0,23$ & $-1,95 \%$ \\
\hline female & $\mathrm{AmE}$ & 67,09 & 66,78 & $-0,31$ & $-0,46 \%$ & 11,17 & 10,78 & $-0,39$ & $-3,49 \%$ \\
\hline female & $\mathrm{BrE}$ & 65,95 & 64,27 & $-1,68$ & $-2,55 \%$ & 16,69 & 14,04 & $-2,65$ & $-15,88 \%$ \\
\hline female & $\mathrm{BrE}$ & 69,46 & 69,99 & 0,53 & $0,76 \%$ & 18,48 & 18,71 & 0,23 & $1,24 \%$ \\
\hline
\end{tabular}




\section{Appendix B}

\begin{tabular}{|c|c|c|c|c|c|}
\hline $\begin{array}{l}\text { Example } \\
\text { number }\end{array}$ & Source & Extract & $\begin{array}{c}\text { Character's } \\
\text { name }\end{array}$ & $\begin{array}{c}\text { Character's } \\
\text { gender }\end{array}$ & $\begin{array}{c}\text { Reader's } \\
\text { initials }\end{array}$ \\
\hline 33 & $\begin{array}{c}\text { A Tale of } \\
\text { Two Cities. } \\
\text { Book 2, } \\
\text { Chapter } 6\end{array}$ & $\begin{array}{l}\text { "I don't know, Mr. Darnay; I told you it was a foolish } \\
\text { fancy, but you asked for it. When I have yielded } \\
\text { myself to it, I have been alone, and then I have } \\
\text { imagined them the footsteps of the people who are to } \\
\text { come into my life, and my father's." }\end{array}$ & $\begin{array}{c}\text { Lucie } \\
\text { Manette }\end{array}$ & female & B.F. \\
\hline 34 & $\begin{array}{c}\text { A Tale of } \\
\text { Two Cities. } \\
\text { Book 2, } \\
\text { Chapter } 6\end{array}$ & $\begin{array}{l}\text { "I don't know, Mr. Darnay; I told you it was a foolish } \\
\text { fancy, but you asked for it. When I have yielded } \\
\text { myself to it, I have been alone, and then I have } \\
\text { imagined them the footsteps of the people who are to } \\
\text { come into my life, and my father's." }\end{array}$ & $\begin{array}{c}\text { Lucie } \\
\text { Manette }\end{array}$ & female & P.A. \\
\hline 35 & \begin{tabular}{|} 
Our \\
Mutual \\
Friend. \\
Book 1, \\
Chapter 15
\end{tabular} & $\begin{array}{l}\text { "And I tell you, my deary," said Mrs Boffin, "that if } \\
\text { you don't close with Mr Rokesmith now at once, and } \\
\underline{\text { if you ever go a muddling yourself }} \\
\text { again with things never meant nor made for you, } \\
\text { you'll have an apoplexy--besides iron-moulding your } \\
\text { linen--and you'll break my heart." }\end{array}$ & $\begin{array}{c}\text { Henrietta } \\
\text { Boffin }\end{array}$ & female & M. \\
\hline 36 & $\begin{array}{l}\text { Our } \\
\text { Mutual } \\
\text { Friend. } \\
\text { Book 1, } \\
\text { Chapter } 15\end{array}$ & $\begin{array}{l}\text { "And I tell you, my deary," said Mrs Boffin, "that if } \\
\text { you don't close with Mr Rokesmith now at once, and } \\
\text { if you ever go a muddling yourself } \\
\text { again with things never meant nor made for you, } \\
\text { you'll have an apoplexy--besides iron-moulding your } \\
\text { linen--and you'll break my heart." }\end{array}$ & $\begin{array}{c}\text { Henrietta } \\
\text { Boffin }\end{array}$ & female & D.J. \\
\hline 37 & $\begin{array}{c}\text { Little } \\
\text { Doritt. } \\
\text { Book 1, } \\
\text { Chapter } 3\end{array}$ & $\begin{array}{l}\text { "I am able," said Mrs Clennam, with a slight motion } \\
\text { of her worsted-muffled right hand toward a chair on } \\
\text { wheels, standing before a tall writing cabinet close } \\
\text { shut up, "I am able to attend to my business duties, } \\
\text { and I am thankful for the privilege. It is a great } \\
\text { privilege. But no more of business on this day." }\end{array}$ & $\begin{array}{c}\text { Mrs. } \\
\text { Clennam }\end{array}$ & female & E.C. \\
\hline 38 & \begin{tabular}{|} 
The \\
Haunted \\
Man and \\
the Ghost's \\
Bargain. \\
Chapter 1
\end{tabular} & $\begin{array}{l}\text { "Indeed I can't tell, sir," said Milly, after thinking a } \\
\text { little, "because I am not at all clever, you know; and I } \\
\text { wanted to be useful to him in making things neat and } \\
\frac{\text { comfortable about him, and employed myself that }}{\text { way. But I know he is poor, and lonely, and I think he }} \\
\underline{\text { is somehow neglected too." }}\end{array}$ & $\begin{array}{c}\text { Milly } \\
\text { Swidger }\end{array}$ & female & R.F. \\
\hline
\end{tabular}




\begin{tabular}{|c|c|c|c|c|c|c|c|c|c|}
\hline $\begin{array}{l}\text { Reader's } \\
\text { gender }\end{array}$ & $\begin{array}{l}\text { Reader's } \\
\text { dialect }\end{array}$ & $\begin{array}{l}\text { Reader's } \\
\text { mean } \\
\text { intensity in } \\
\text { the whole } \\
\text { chapter in } \\
\text { dB }\end{array}$ & $\begin{array}{c}\text { Mean } \\
\text { intensity in } \\
\text { extract in } \\
\text { dB }\end{array}$ & $\begin{array}{c}\text { Shift of } \\
\text { intensity in } \\
\text { dB }\end{array}$ & $\begin{array}{c}\text { Shift of } \\
\text { intensity in } \\
\text { percentages }\end{array}$ & $\begin{array}{l}\text { Reader's } \\
\text { SD of } \\
\text { intensity in } \\
\text { the whole } \\
\text { chapter in } \\
\text { dB }\end{array}$ & $\begin{array}{c}\text { SD of } \\
\text { intensity in } \\
\text { extract in } \\
\text { dB }\end{array}$ & $\begin{array}{c}\text { Shift of SD } \\
\text { of intensity } \\
\text { in } d B\end{array}$ & $\begin{array}{c}\text { Shift of SD } \\
\text { of intensity } \\
\text { in } \\
\text { percentages }\end{array}$ \\
\hline male & AmE & 75,02 & 65,28 & $-9,74$ & $-12,98 \%$ & 11,69 & 21,36 & 9,67 & $82,72 \%$ \\
\hline male & $\mathrm{BrE}$ & 74,57 & 75,53 & 0,96 & $1,29 \%$ & 12,68 & 12,58 & $-0,1$ & $-0,79 \%$ \\
\hline male & $\mathrm{AmE}$ & 64,38 & 63,75 & $-0,63$ & $-0,98 \%$ & 13,13 & 11,35 & $-1,78$ & $-13,56 \%$ \\
\hline male & AmE & 71,28 & 74,25 & 2,97 & $4,17 \%$ & 12,4 & 11,54 & $-0,86$ & $-6,94 \%$ \\
\hline male & $\mathrm{BrE}$ & 76,28 & 76,91 & 0,63 & $0,83 \%$ & 81,86 & 21,04 & $-60,82$ & $-74,30 \%$ \\
\hline male & AmE & 69,65 & 69,89 & 0,24 & $0,34 \%$ & 20,25 & 19,26 & $-0,99$ & $-4,89 \%$ \\
\hline
\end{tabular}




\begin{tabular}{|c|c|c|c|c|c|}
\hline $\begin{array}{c}\text { Example } \\
\text { number }\end{array}$ & Source & Extract & $\begin{array}{c}\text { Character's } \\
\text { name }\end{array}$ & $\begin{array}{c}\text { Character's } \\
\text { gender }\end{array}$ & $\begin{array}{c}\text { Reader's } \\
\text { initials }\end{array}$ \\
\hline 39 & $\begin{array}{l}\text { The } \\
\text { Pickwick } \\
\text { Papers. } \\
\text { Chapter } 4\end{array}$ & $\begin{array}{l}\text { "You were going to say that Isabel stoops-I know } \\
\text { you were-you men are such observers. Well, so she } \\
\text { does; it can't be denied; and, certainly, if there is one } \\
\text { thing more than another that makes a girl look ugly it } \\
\text { is stooping. I often tell her that when she gets a little } \\
\text { older she'll be quite frightful.". }\end{array}$ & $\begin{array}{l}\text { Rachael } \\
\text { Wardle }\end{array}$ & female & S.E. \\
\hline 40 & $\begin{array}{c}\text { Oliver } \\
\text { Twist. } \\
\text { Chapter } 30\end{array}$ & $\begin{array}{l}\text { "But even if he has been wicked," pursued Rose, } \\
\text { "think how young he is; think that he may never have } \\
\text { known a mother's love, or the comfort of a home; that } \\
\text { kll-usage and blows, or the want of bread, may have } \\
\text { driven him to herd with men who have forced him to } \\
\text { guilt. Aunt, dear aunt, for mercy's sake, think of this, } \\
\text { before you let them drag this sick child to a prison, } \\
\text { which in any case must be the grave of all his chances } \\
\text { of amendment." }\end{array}$ & $\begin{array}{c}\text { Rose } \\
\text { Maylie }\end{array}$ & female & R.D. \\
\hline 41 & $\begin{array}{c}\text { Oliver } \\
\text { Twist. } \\
\text { Chapter } 30\end{array}$ & $\begin{array}{l}\text { "But even if he has been wicked," pursued Rose, } \\
\text { "think how young he is; think that he may never have } \\
\text { known a mother's love, or the comfort of a home; that } \\
\text { ill-usage and blows, or the want of bread, may have } \\
\text { driven him to herd with men who have forced him to } \\
\text { guilt. Aunt, dear aunt, for mercy's sake, think of this, } \\
\text { before you let them drag this sick child to a prison, } \\
\text { which in any case must be the grave of all his chances } \\
\text { of amendment." }\end{array}$ & $\begin{array}{c}\text { Rose } \\
\text { Maylie }\end{array}$ & female & P.A. \\
\hline 42 & $\begin{array}{l}\text { Christmas } \\
\text { Carol. } \\
\text { Stave } 4\end{array}$ & $\begin{array}{l}\text { "They're better now again," said Cratchit's wife. "It } \\
\text { makes them weak by candle-light; and I wouldn't } \\
\text { show weak eyes to your father, when he comes home, } \\
\text { for the world. It must be near his time." }\end{array}$ & $\begin{array}{c}\text { Mrs. } \\
\text { Cratchit }\end{array}$ & female & J.F. \\
\hline 43 & $\begin{array}{l}\text { Christmas } \\
\text { Carol. } \\
\text { Stave } 4\end{array}$ & $\begin{array}{l}\text { "They're better now again," said Cratchit's wife. "It } \\
\text { makes them weak by candle-light; and I wouldn't } \\
\text { show weak eyes to your father, when he comes home, } \\
\text { for the world. It must be near his time." }\end{array}$ & $\begin{array}{l}\text { Mrs. } \\
\text { Cratchit }\end{array}$ & female & G.H. \\
\hline 44 & $\begin{array}{l}\text { Christmas } \\
\text { Carol. } \\
\text { Stave } 4\end{array}$ & $\begin{array}{l}\text { "They're better now again," said Cratchit's wife. "It } \\
\text { makes them weak by candle-light; and I wouldn't } \\
\text { show weak eyes to your father, when he comes home, } \\
\text { for the world. It must be near his time." }\end{array}$ & $\begin{array}{c}\text { Mrs. } \\
\text { Cratchit }\end{array}$ & female & K.M. \\
\hline
\end{tabular}




\begin{tabular}{|c|c|c|c|c|c|c|c|c|c|}
\hline $\begin{array}{l}\text { Reader's } \\
\text { gender }\end{array}$ & $\begin{array}{c}\text { Reader's } \\
\text { dialect }\end{array}$ & $\begin{array}{l}\text { Reader's } \\
\text { mean } \\
\text { intensity in } \\
\text { the whole } \\
\text { chapter in } \\
\text { dB } \\
\end{array}$ & $\begin{array}{c}\text { Mean } \\
\text { intensity in } \\
\text { extract in } \\
\mathrm{dB}\end{array}$ & $\begin{array}{l}\text { Shift of } \\
\text { intensity in } \\
\quad d B\end{array}$ & $\begin{array}{c}\text { Shift of } \\
\text { intensity in } \\
\text { percentages }\end{array}$ & $\begin{array}{l}\text { Reader's } \\
\text { SD of } \\
\text { intensity in } \\
\text { the whole } \\
\text { chapter in } \\
\text { dB }\end{array}$ & $\begin{array}{c}\text { SD of } \\
\text { intensity in } \\
\text { extract in } \\
\text { dB }\end{array}$ & $\begin{array}{l}\text { Shift of SD } \\
\text { of intensity } \\
\text { in dB }\end{array}$ & $\begin{array}{l}\text { Shift of SD } \\
\text { of intensity } \\
\text { in } \\
\text { percentages }\end{array}$ \\
\hline male & $\mathrm{BrE}$ & 66,2 & 65,99 & $-0,21$ & $-0,32 \%$ & 10,74 & 10,06 & $-0,68$ & $-6,33 \%$ \\
\hline male & $\mathrm{BrE}$ & 66,68 & 69,42 & 2,74 & $4,11 \%$ & 18,52 & 16,6 & $-1,92$ & $-10,37 \%$ \\
\hline male & $\mathrm{BrE}$ & 61,42 & 64,21 & 2,79 & $4,54 \%$ & 13,99 & 13,46 & $-0,53$ & $-3,79 \%$ \\
\hline male & $\mathrm{AmE}$ & 69,97 & 67,5 & $-2,47$ & $-3,53 \%$ & 14,45 & 12,93 & $-1,52$ & $-10,52 \%$ \\
\hline male & $\mathrm{AmE}$ & 68,72 & 61,33 & $-7,39$ & $-10,75 \%$ & 14,17 & 10,17 & -4 & $-28,23 \%$ \\
\hline male & AmE & 68,42 & 66,14 & $-2,28$ & $-3,33 \%$ & 19,6 & 19,73 & 0,13 & $0,66 \%$ \\
\hline
\end{tabular}




\begin{tabular}{|c|c|c|c|c|c|}
\hline $\begin{array}{c}\text { Example } \\
\text { number }\end{array}$ & Source & Extract & $\begin{array}{c}\text { Character's } \\
\text { name }\end{array}$ & $\begin{array}{c}\text { Character's } \\
\text { gender }\end{array}$ & $\begin{array}{l}\text { Reader's } \\
\text { initials }\end{array}$ \\
\hline 45 & $\begin{array}{l}\text { Christmas } \\
\text { Carol. } \\
\text { Stave } 4\end{array}$ & $\begin{array}{l}\text { "They're better now again," said Cratchit's wife. "It } \\
\text { makes them weak by candle-light; and I wouldn't } \\
\text { show weak eyes to your father, when he comes } \\
\text { home, for the world. It must be near his time." }\end{array}$ & $\begin{array}{c}\text { Mrs. } \\
\text { Cratchit }\end{array}$ & female & H.M. \\
\hline 46 & $\begin{array}{l}\text { Life and } \\
\text { Adventures } \\
\text { of Martin } \\
\text { Chuzzlewit. } \\
\text { Chapter } 2\end{array}$ & $\begin{array}{l}\text { "He slept last night at the Dragon," returned the } \\
\text { young lady, "and had Mr Pinch to dine with him. } \\
\text { They spent the evening together, and Mr Pinch was } \\
\text { not home till very late." }\end{array}$ & $\begin{array}{l}\text { Charity } \\
\text { Pecksniff }\end{array}$ & female & P.K. \\
\hline 47 & $\begin{array}{c}\text { The } \\
\text { Mistery of } \\
\text { Edwin } \\
\text { Drood. } \\
\text { Chapter } 6\end{array}$ & $\begin{array}{l}\text { "You must take some wine, sir," said Mrs. Tope, "and } \\
\text { the jelly that I had ready for you, and that you wouldn't } \\
\text { put your lips to at noon, though I warned you what } \\
\text { would come of it, you know, and you not breakfasted; } \\
\begin{array}{l}\text { and you must have a wing of the roast fowl that has } \\
\text { been put back twenty times if it's been put back once. It }\end{array} \\
\begin{array}{c}\text { shall all be on table in five minutes, and this good } \\
\text { gentleman belike will stop and see you take it." }\end{array}\end{array}$ & Mrs. Tope & female & A.C. \\
\hline 48 & $\begin{array}{c}\text { Our } \\
\text { Mutual } \\
\text { Friend. } \\
\text { Book 1, } \\
\text { Chapter 6 }\end{array}$ & $\begin{array}{l}\text { "Well, Miss Abbey, respectfully meaning no offence } \\
\text { to you, it would be some satisfaction to a man's } \\
\text { mind, to understand why the Fellowship Porters is } \\
\frac{\text { not to be free to such as me, and is to be free to such }}{\text { as Gaffer." }}\end{array}$ & $\begin{array}{c}\text { Abbey } \\
\text { Potterson }\end{array}$ & female & A.M. \\
\hline 49 & \begin{tabular}{|} 
Our \\
Mutual \\
Friend. \\
Book 1, \\
Chapter 15
\end{tabular} & $\begin{array}{l}\text { "And I tell you, my deary," said Mrs Boffin, "that if } \\
\text { you don't close with Mr Rokesmith now at once, and } \\
\frac{\text { if you ever go a muddling yourself again with things }}{\text { never meant nor made for you, you'll have an }} \\
\frac{\text { apoplexy--besides iron-moulding your linen--and }}{\text { you'll break my heart." }}\end{array}$ & $\begin{array}{c}\text { Henrietta } \\
\text { Boffin }\end{array}$ & female & M.N. \\
\hline 50 & $\begin{array}{l}\text { Bleak } \\
\text { House. } \\
\text { Chapter } 7\end{array}$ & $\begin{array}{l}\text { "Yes, child. She is daughter of a widow in the } \\
\text { village. Maids are so hard to teach, now-a-days, that } \\
\text { I have put her about me young. She's an apt scholar } \\
\frac{\text { and will do well. She shows the house already, very }}{\text { pretty. She lives with me at my table here." }}\end{array}$ & $\begin{array}{c}\text { Mrs. } \\
\text { Rouncewell }\end{array}$ & female & C.L. \\
\hline
\end{tabular}




\begin{tabular}{|c|c|c|c|c|c|c|c|c|c|}
\hline $\begin{array}{l}\text { Reader's } \\
\text { gender }\end{array}$ & $\begin{array}{c}\text { Reader's } \\
\text { dialect }\end{array}$ & \begin{tabular}{|c} 
Reader's \\
mean \\
intensity in \\
the whole \\
chapter in \\
dB
\end{tabular} & $\begin{array}{c}\text { Mean } \\
\text { intensity in } \\
\text { extract in } \\
\text { dB }\end{array}$ & $\begin{array}{c}\text { Shift of } \\
\text { intensity in } \\
\text { dB }\end{array}$ & $\begin{array}{c}\text { Shift of } \\
\text { intensity in } \\
\text { percentages }\end{array}$ & \begin{tabular}{|} 
Reader's \\
SD of \\
intensity in \\
the whole \\
chapter in \\
dB
\end{tabular} & $\begin{array}{c}\text { SD of } \\
\text { intensity in } \\
\text { extract in } \\
\text { dB }\end{array}$ & $\begin{array}{l}\text { Shift of SD } \\
\text { of intensity } \\
\text { in } \mathrm{dB}\end{array}$ & $\begin{array}{c}\text { Shift of SD } \\
\text { of intensity } \\
\text { in } \\
\text { percentages }\end{array}$ \\
\hline male & AmE & 65,65 & 62,52 & $-3,13$ & $-4,77 \%$ & 11,97 & 11,26 & $-0,71$ & $-5,93 \%$ \\
\hline male & $\mathrm{BrE}$ & 67,29 & 65,78 & $-1,51$ & $-2,24 \%$ & 17,18 & 14,85 & $-2,33$ & $-13,56 \%$ \\
\hline male & $\mathrm{BrE}$ & 73,11 & 74,06 & 0,95 & $1,30 \%$ & 12,44 & 11,86 & $-0,58$ & $-4,66 \%$ \\
\hline male & $\mathrm{BrE}$ & 70,01 & 68,2 & $-1,81$ & $-2,59 \%$ & 15,58 & 12,85 & $-2,73$ & $-17,52 \%$ \\
\hline female & $\mathrm{BrE}$ & 70,22 & 71,4 & 1,18 & $1,68 \%$ & 17,99 & 16,03 & $-1,96$ & $-10,89 \%$ \\
\hline female & AmE & 70,04 & 71,25 & 1,21 & $1,73 \%$ & 24,96 & 20,21 & $-4,75$ & $-19,03 \%$ \\
\hline
\end{tabular}




\begin{tabular}{|c|c|c|c|c|c|}
\hline $\begin{array}{c}\text { Example } \\
\text { number }\end{array}$ & Source & Extract & $\begin{array}{c}\text { Character's } \\
\text { name }\end{array}$ & $\begin{array}{c}\text { Character's } \\
\text { gender }\end{array}$ & $\begin{array}{c}\text { Reader's } \\
\text { initials }\end{array}$ \\
\hline 52 & $\begin{array}{l}\text { The } \\
\text { Pickwick } \\
\text { Papers. } \\
\text { Chapter } 4\end{array}$ & $\begin{array}{l}\text { "You were going to say that Isabel stoops-I know } \\
\text { you were-you men are such observers. Well, so } \\
\text { she does; it can't be denied; and, certainly, if there } \\
\text { is one thing more than another that makes a girl } \\
\text { look ugly it is stooping. I often tell her that when } \\
\text { she gets a little older she'll be quite frightful." }\end{array}$ & $\begin{array}{l}\text { Rachael } \\
\text { Wardle }\end{array}$ & female & D.L. \\
\hline 53 & $\begin{array}{c}\text { Oliver } \\
\text { Twist. } \\
\text { Chapter } 2\end{array}$ & $\begin{array}{l}\text { "I'm sure Mr. Bumble, that I was only a telling one or } \\
\text { two of the dear children as is so fond of you, that it was } \\
\text { you a coming," replied Mrs. Mann with great humility. }\end{array}$ & Mrs. Mann & female & K.P. \\
\hline 54 & $\begin{array}{c}\text { Oliver } \\
\text { Twist. } \\
\text { Chapter } 35\end{array}$ & 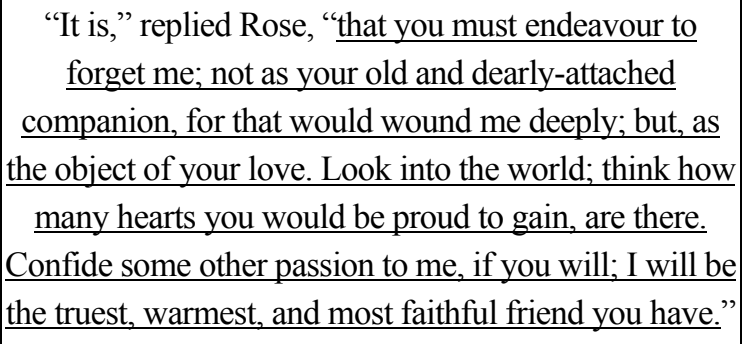 & $\begin{array}{c}\text { Rose } \\
\text { Maylie }\end{array}$ & female & C.S. \\
\hline 55 & $\begin{array}{c}\text { David } \\
\text { Copperfield } \\
\text { Chapter } 8\end{array}$ & $\begin{array}{l}\text { "Well then, don't talk about such uncomfortable } \\
\text { things, there's a good soul," said my mother. "Miss } \\
\text { Betsey is shut up in her cottage by the sea, no doubt, } \\
\frac{\text { and will remain there. At all events, she is not likely }}{\underline{\text { ever to trouble us again." }}}\end{array}$ & $\begin{array}{c}\text { Clara } \\
\text { Copperfield }\end{array}$ & female & L.A. \\
\hline 56 & $\begin{array}{l}\text { Christmas } \\
\text { Carol. } \\
\text { Stave } 4\end{array}$ & $\begin{array}{l}\text { "They're better now again," said Cratchit's wife. "It } \\
\text { makes them weak by candle-light; and I wouldn't } \\
\underline{\text { show weak eyes to your father, when he comes }} \\
\underline{\text { home, for the world. It must be near his time." }}\end{array}$ & $\begin{array}{c}\text { Mrs. } \\
\text { Cratchit }\end{array}$ & female & K.S. \\
\hline 57 & $\begin{array}{l}\text { The Old } \\
\text { Curiosity } \\
\text { Shop. } \\
\text { Chater } 4\end{array}$ & $\begin{array}{l}\text { "Very well," said Mrs Quilp, nodding her head, "as } \\
\text { I said just now, it's very easy to talk, but I say again } \\
\text { that I know - that I'm sure-Quilp has such a way } \\
\text { with him when he likes, that the best looking } \\
\text { woman here couldn't refuse him if I was dead, and } \\
\text { she was free, and he chose to make love to her." }\end{array}$ & $\begin{array}{l}\text { Betsy } \\
\text { Quilp }\end{array}$ & female & E. \\
\hline 58 & $\begin{array}{l}\text { A Tale of } \\
\text { Two Cities. } \\
\text { Book } 2 \text {, } \\
\text { Chapter } 6\end{array}$ & 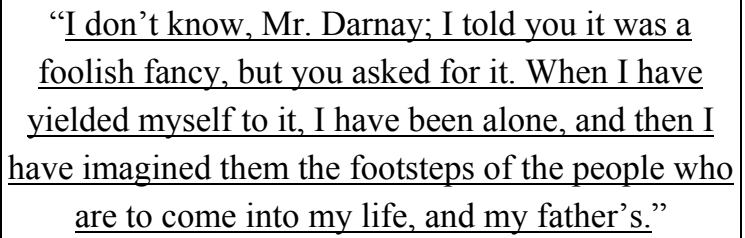 & $\begin{array}{c}\text { Lucie } \\
\text { Manette }\end{array}$ & female & $\mathrm{T}$. \\
\hline
\end{tabular}




\begin{tabular}{|c|c|c|c|c|c|c|c|c|c|}
\hline $\begin{array}{l}\text { Reader's } \\
\text { gender }\end{array}$ & $\begin{array}{l}\text { Reader's } \\
\text { dialect }\end{array}$ & $\begin{array}{l}\text { Reader's } \\
\text { mean } \\
\text { intensity in } \\
\text { the whole } \\
\text { chapter in } \\
\text { dB } \\
\end{array}$ & $\begin{array}{c}\text { Mean } \\
\text { intensity in } \\
\text { extract in } \\
\text { dB }\end{array}$ & $\begin{array}{c}\text { Shift of } \\
\text { intensity in } \\
\text { dB }\end{array}$ & $\begin{array}{c}\text { Shift of } \\
\text { intensity in } \\
\text { percentages }\end{array}$ & \begin{tabular}{|c|} 
Reader's \\
SD of \\
intensity in \\
the whole \\
chapter in \\
dB \\
\end{tabular} & $\begin{array}{c}\text { SD of } \\
\text { intensity in } \\
\text { extract in } \\
\text { dB }\end{array}$ & $\begin{array}{l}\text { Shift of SD } \\
\text { of intensity } \\
\text { in } \mathrm{dB}\end{array}$ & $\begin{array}{l}\text { Shift of SD } \\
\text { of intensity } \\
\text { in } \\
\text { percentages }\end{array}$ \\
\hline female & $\mathrm{AmE}$ & 69,42 & 68,25 & $-1,17$ & $-1,69 \%$ & 13,32 & 11,97 & $-1,35$ & $-10,14 \%$ \\
\hline female & $\mathrm{AmE}$ & 64,21 & 66,08 & 1,87 & $2,91 \%$ & 15,67 & 15,94 & 0,27 & $1,72 \%$ \\
\hline female & $\mathrm{BrE}$ & 65,57 & 64,65 & $-0,92$ & $-1,40 \%$ & 33,03 & 21,19 & $-11,84$ & $-35,85 \%$ \\
\hline female & $\mathrm{AmE}$ & 69,45 & 69,48 & 0,03 & $0,04 \%$ & 13,8 & 11,79 & $-2,01$ & $-14,57 \%$ \\
\hline female & AmE & 68,16 & 69,75 & 1,59 & $2,33 \%$ & 18,41 & 16,18 & $-2,23$ & $-12,11 \%$ \\
\hline female & $\mathrm{BrE}$ & 73,81 & 73,66 & $-0,15$ & $-0,20 \%$ & 16,08 & 14,65 & $-1,43$ & $-8,89 \%$ \\
\hline female & $\mathrm{AmE}$ & 66,96 & 65,82 & $-1,14$ & $-1,70 \%$ & 12,16 & 11,07 & $-1,09$ & $-8,96 \%$ \\
\hline
\end{tabular}




\begin{tabular}{|c|c|c|c|c|c|}
\hline $\begin{array}{c}\text { Example } \\
\text { number }\end{array}$ & Source & Extract & $\begin{array}{c}\text { Character's } \\
\text { name }\end{array}$ & $\begin{array}{l}\text { Character's } \\
\text { gender }\end{array}$ & $\begin{array}{c}\text { Reader's } \\
\text { initials }\end{array}$ \\
\hline 59 & $\begin{array}{l}\text { Our } \\
\text { Mutual } \\
\text { Friend. } \\
\text { Book 1, } \\
\text { Chapter } 4\end{array}$ & $\begin{array}{l}\text { "Yes," said Mrs Wilfer, "the man came himself with a } \\
\text { pair of pincers, and took it off, and took it away. He } \\
\text { said that as he had no expectation of ever being paid } \\
\text { for it, and as he had an order for another LADIES' } \\
\frac{\text { SCHOOL door-plate, it was better (burnished up) for }}{\text { the interests of all parties." }}\end{array}$ & $\begin{array}{c}\text { Mrs } \\
\text { Wilfer }\end{array}$ & female & O.D. \\
\hline 60 & $\begin{array}{l}\text { Our } \\
\text { Mutual } \\
\text { Friend. } \\
\text { Book 2, } \\
\text { Chapter 2 }\end{array}$ & $\begin{array}{l}\text { "I have been thinking," Jenny went on, "as I sat at work } \\
\text { to-day, what a thing it would be, if I should be able to } \\
\text { have your company till I am married, or at least courted. } \\
\text { Because when I am courted, I shall make Him do some } \\
\text { of the things that you do for me. He couldn't brush my } \\
\text { hair like you do, or help me up and down stairs like you } \\
\frac{\text { do, and he couldn't do anything like you do; but he could }}{\text { take my work home, and he could call for orders in his }} \\
\text { clumsy way. And he shall too." }\end{array}$ & $\begin{array}{l}\text { Jenny } \\
\text { Wren } \\
\text { (Fanny } \\
\text { Cleaver) }\end{array}$ & female & K.F. \\
\hline 61 & $\begin{array}{c}\text { Our } \\
\text { Mutual } \\
\text { Friend. } \\
\text { Book 2, } \\
\text { Chapter 16 }\end{array}$ & \begin{tabular}{|l} 
"For I aint, you must know," said Betty, "much of a \\
hand at reading writing-hand, though I can read my \\
Bible and most print. And I do love a newspaper. You \\
mightn't think it, but Sloppy is a beautiful reader of a \\
newspaper. He do the Police in different voices."
\end{tabular} & $\begin{array}{l}\text { Betty } \\
\text { Higden }\end{array}$ & female & J.B. \\
\hline 62 & $\begin{array}{l}\text { Our } \\
\text { Mutual } \\
\text { Friend. } \\
\text { Book 2, } \\
\text { Chapter } 4\end{array}$ & $\begin{array}{l}\text { "Alfred, my dear, Mr Fledgeby very justly says, } \\
\text { apropos of the last scene, that true constancy would } \\
\text { not require any such stimulant as the stage deems } \\
\text { necessary." }\end{array}$ & $\begin{array}{c}\text { Mrs. } \\
\text { Sophronia } \\
\text { Lammle }\end{array}$ & female & R.N. \\
\hline 63 & $\begin{array}{c}\text { Oliver } \\
\text { Twist. } \\
\text { Chapter } 41\end{array}$ & \begin{tabular}{|c} 
"I believe," interposed Miss Maylie, "that at this period of \\
our interview, I need not give that gentleman the trouble \\
of going away. If I am correctly informed, he is cognizant \\
of the business on which I wish to speak to you."
\end{tabular} & $\begin{array}{c}\text { Mrs. } \\
\text { Maylie }\end{array}$ & female & A.V. \\
\hline 64 & $\begin{array}{c}\text { Jane } \\
\text { Austen. } \\
\text { Northanger } \\
\text { Abbey. } \\
\text { Chapter } 6\end{array}$ & $\begin{array}{l}\text { "I will read you their names directly; here they are, in } \\
\text { my pocketbook. Castle of Wolfenbach, Clermont, } \\
\text { Mysterious Warnings, Necromancer of the Black } \\
\text { Forest, Midnight Bell, Orphan of the Rhine, and } \\
\text { Horrid Mysteries. Those will last us some time." }\end{array}$ & $\begin{array}{l}\text { Isabella } \\
\text { Thorpe }\end{array}$ & female & V. \\
\hline
\end{tabular}




\begin{tabular}{|c|c|c|c|c|c|c|c|c|c|}
\hline $\begin{array}{l}\text { Reader's } \\
\text { gender }\end{array}$ & $\begin{array}{c}\text { Reader's } \\
\text { dialect }\end{array}$ & $\begin{array}{l}\text { Reader's } \\
\text { mean } \\
\text { intensity in } \\
\text { the whole } \\
\text { chapter in } \\
\text { dB } \\
\end{array}$ & $\begin{array}{c}\text { Mean } \\
\text { intensity in } \\
\text { extract in } \\
\text { dB }\end{array}$ & $\begin{array}{c}\text { Shift of } \\
\text { intensity in } \\
\text { dB }\end{array}$ & $\begin{array}{c}\text { Shift of } \\
\text { intensity in } \\
\text { percentages }\end{array}$ & $\begin{array}{l}\text { Reader's } \\
\text { SD of } \\
\text { intensity in } \\
\text { the whole } \\
\text { chapter in } \\
\text { dB }\end{array}$ & $\begin{array}{c}\text { SD of } \\
\text { intensity in } \\
\text { extract in } \\
\text { dB }\end{array}$ & $\begin{array}{c}\text { Shift of SD } \\
\text { of intensity } \\
\text { in } \mathrm{dB}\end{array}$ & $\begin{array}{l}\text { Shift of SD } \\
\text { of intensity } \\
\text { in } \\
\text { percentages }\end{array}$ \\
\hline female & $\mathrm{BrE}$ & 67,28 & 69,41 & 2,13 & $3,17 \%$ & 14,02 & 15,93 & 1,91 & $13,62 \%$ \\
\hline female & $\mathrm{AmE}$ & 62,35 & 60,96 & $-1,39$ & $-2,23 \%$ & 10,04 & 8,49 & $-1,55$ & $-15,44 \%$ \\
\hline female & $\mathrm{BrE}$ & 66,39 & 65,73 & $-0,66$ & $-0,99 \%$ & 11,81 & 11,48 & $-0,33$ & $-2,79 \%$ \\
\hline female & $\mathrm{AmE}$ & 67,42 & 67,55 & 0,13 & $0,19 \%$ & 11,3 & 10,96 & $-0,34$ & $-3,01 \%$ \\
\hline female & $\mathrm{BrE}$ & 65,95 & 65,24 & $-0,71$ & $-1,08 \%$ & 16,69 & 12,95 & $-3,74$ & $-22,41 \%$ \\
\hline female & $\mathrm{BrE}$ & 68,48 & 69,25 & 0,77 & $1,12 \%$ & 33,47 & 25,9 & $-7,57$ & $-22,62 \%$ \\
\hline
\end{tabular}

